Old Dominion University

ODU Digital Commons

OEAS Faculty Publications

Ocean, Earth \& Atmospheric Sciences

2003

\title{
The Role of Physical, Chemical, and Microbial Heterogeneity on the Field-Scale Transport and Attachment of Bacteria
}

\author{
Brian J. Mailloux \\ Mark E. Fuller \\ Tullis C. Onstott \\ James Hall \\ Hailiang Dong \\ See next page for additional authors
}

Follow this and additional works at: https://digitalcommons.odu.edu/oeas_fac_pubs

Part of the Hydrology Commons, Marine Biology Commons, Microbiology Commons, and the Water Resource Management Commons

\section{Repository Citation}

Mailloux, Brian J.; Fuller, Mark E.; Onstott, Tullis C.; Hall, James; Dong, Hailiang; Deflaun, Mary F.; Streger, Sheryl H.; Rothmel, Randi K.; Green, Maria; Swift, Donald J. P.; and Radke, Jon, "The Role of Physical, Chemical, and Microbial Heterogeneity on the Field-Scale Transport and Attachment of Bacteria" (2003). OEAS Faculty Publications. 310.

https://digitalcommons.odu.edu/oeas_fac_pubs/310

\section{Original Publication Citation}

Mailloux, B. J., Fuller, M. E., Onstott, T. C., Hall, J., Dong, H. L., DeFlaun, M. F., ... Radke, J. (2003). The role of physical, chemical, and microbial heterogeneity on the field-scale transport and attachment of bacteria. Water Resources Research, 39(6), 1142. doi: $10.1029 / 2002$ wr001591 


\section{Authors}

Brian J. Mailloux, Mark E. Fuller, Tullis C. Onstott, James Hall, Hailiang Dong, Mary F. Deflaun, Sheryl H.

Streger, Randi K. Rothmel, Maria Green, Donald J. P. Swift, and Jon Radke 


\title{
The role of physical, chemical, and microbial heterogeneity on the field-scale transport and attachment of bacteria
}

\author{
Brian J. Mailloux, ${ }^{1,2}$ Mark E. Fuller, ${ }^{3}$ Tullis C. Onstott, ${ }^{1}$ James Hall, ${ }^{1}$ Hailiang Dong, ${ }^{1,4}$ \\ Mary F. DeFlaun, ${ }^{3,5}$ Sheryl H. Streger, ${ }^{3}$ Randi K. Rothmel, ${ }^{3}$ Maria Green, ${ }^{6}$ \\ Donald J. P. Swift, ${ }^{6}$ and Jon Radke ${ }^{7}$ \\ Received 16 July 2002; revised 5 February 2003; accepted 11 March 2003; published 6 June 2003.
}

[1] A field-scale bacterial transport experiment was conducted at the Narrow Channel Focus Area of the South Oyster field site located in Oyster, Virginia. The goal of the field experiment was to determine the relative influence of subsurface heterogeneity and microbial population parameters on flow direction, velocity, and attachment of bacteria at the field scale. The field results were compared with results from laboratory-scale column experiments to develop a method for predicting field-scale bacterial transport. The field site is a shallow, sandy, unconfined, aerobic aquifer that has been characterized by geophysical, sedimentological, and hydrogeological methods. Comamonas sp. strain DA001 and a conservative tracer, bromide (Br), were injected into an area of high permeability for 12 hours. The $\mathrm{Br}$ and bacterial concentrations in the groundwater were monitored for 1 week at 192 sampling ports spaced over a 2-m vertical zone located from 0.5 to $7 \mathrm{~m}$ down-gradient of the injection well. The bacterial and $\mathrm{Br}$ plume was observed to move past 95 sampling ports. The densely characterized field site enabled the comparison of variations in DA001 transport to the aquifer properties. The velocity of the injected plume was correlated with geophysical estimates of hydraulic conductivity. The bacterial and Br plume appeared to follow flow paths not coincident with the hydraulic gradient but through a zone of higher permeability located off the flow axis. The amount of breakthrough of the bacteria was similar in both the high and low permeability layers with only a weak correlation between the observed hydraulic conductivity and amount of bacterial breakthrough. The uniformity in the observed attachment rates across varying grain sizes could be explained by heterogeneity of microbial properties within the single strain of injected bacteria. Application of colloid filtration theory to the field data indicated that variations in the microbial population were described by a lognormal distribution of the collision efficiency $(\alpha)$. Core-scale studies were used to predict the $\alpha$ distribution and field-scale transport distances of DA001. In sandy aquifers, physical heterogeneity may play a secondary role in controlling field-scale bacterial transport, and future research should focus on the microbial factors affecting transport. INDEX TERMS: 1829 Hydrology: Groundwater hydrology; 1832 Hydrology: Groundwater transport; 1899 Hydrology: General or miscellaneous; KEYWORDS: bacterial transport, geomicrobiology, groundwater transport

Citation: Mailloux, B. J., et al., The role of physical, chemical, and microbial heterogeneity on the field-scale transport and attachment of bacteria, Water Resour. Res., 39(6), 1142, doi:10.1029/2002WR001591, 2003.

\footnotetext{
${ }^{1}$ Department of Geosciences, Princeton University, Princeton, New Jersey, USA.

${ }^{2}$ Now at Columbia Earth Institute, Columbia University, New York, New York, USA.

${ }^{3}$ Envirogen, Inc., Princeton Research Center, Lawrenceville, New Jersey, USA.

${ }^{4}$ Now at Department of Geology, Miami University, Oxford, Ohio, USA. USA.

${ }^{5}$ Now at Geosyntec Consultants, Research Park, Princeton, New Jersey,

${ }^{6}$ Ocean, Earth, and Atmospheric Sciences, Old Dominion University, Norfolk, Virginia, USA.

${ }^{7}$ Golder Associates, Atlanta, Georgia, USA.
}

Copyright 2003 by the American Geophysical Union. 0043-1397/03/2002WR001591

\section{Introduction}

[2] The injection or bioaugmentation of indigenous or exogenous microorganisms with activities designed to accelerate the degradation of environmental pollutants has been shown to be a viable remedial option for contaminated shallow aquifers located in unconsolidated sediments [Duba et al., 1996; Hyndman et al., 2000; Steffan et al., 1999]. Bioaugmentation may prove beneficial at contaminated sites where indigenous microorganisms capable of degrading the contaminants do not exist or are present in low numbers [Ellis et al., 2000]. In order for this remedial strategy to prove successful, high concentrations of bacteria and required nutrients need to be delivered to the most heavily contaminated portions of the aquifer [Duba et al., 1996; 
Ellis et al., 2000; Hyndman et al., 2000; Steffan et al., 1999].

[3] Knowledge about the transport of bacteria through unconsolidated porous media is derived primarily from laboratory studies. These studies have systematically examined the impact of grain size, mineralogy, microbial physiology, groundwater geochemistry, and flow hydrodynamics on transport [Albinger et al., 1994; Camesano and Logan, 1998; Dong et al., 2002a; Fuller et al., 2000a; Johnson et al., 1996; Knapp et al., 1998; Scholl and Harvey, 1992; Scholl et al., 1990]. Field-scale experiments that have examined the transport of bacteria are limited and can be grouped with studies of colloids, bacteriophage, viruses, and microspheres (biocolloids) [Bales et al., 1995; Harvey, 1997; Ryan and Elimelech, 1996]. These studies have been effective in probing the geochemical and microbiological controls on transport in light of public health concerns and colloid enhanced contaminant transport [Bales et al., 1991, 1993, 1995, 1997; Harvey and Garabedian, 1991; Harvey et al., 1989, 1995; McCarthy and Zachara, 1989; McKay et al., 1993a, 1993b, 2000; Pieper et al., 1997; Ryan et al., 1999]. Geochemical effects have been examined by injecting biocolloids into contaminated versus uncontaminated portions of an aquifer [Pieper et al., 1997], altering the groundwater chemistry [Pieper et al., 1997], or by following the initial injection with an injection of water with an altered chemistry [Bales et al., 1997; Ryan et al., 1999]. A second approach has been to simultaneously inject multiple types of biocolloids or a diverse population of bacteria to observe how colloidal properties can affect transport [Harvey and Garabedian, 1991; Harvey et al., 1989, 1995, 1993].

[4] During bioaugmentation, a single strain of bacteria with selected capabilities is grown ex situ to high concentrations and then injected into a contaminated aquifer. Subsurface heterogeneity will effect the flow direction, the flow velocity, and the attachment rate of the injected bacteria. Fluid flow will be focused through and flow faster in high-permeability strata. These high-permeability layers should be zones of low bacterial attachment rates; whereas low-permeability layers should be areas of low flow velocity and high bacterial attachment rates. Laboratory and theoretical studies have suggested that physical heterogeneity of the porous medium, such as variations in average grain size, may be the predominant factor in determining the amount of bacterial attachment [Campbell Rehmann and Welty, 1999; Fontes et al., 1991; Ren et al., 2000]. Harvey et al. [1993] proposed that physical heterogeneity plays a significant role in controlling field-scale bacterial transport in sandy aquifers, but the effects have only been demonstrated at the smaller scale [Dong et al., 2002a; Morley et al., 1998; Murphy et al., 1997]. Testing for a correlation between bacterial transport and physical heterogeneity at the field scale requires high-resolution data and intensive media (or site) characterization, which prior to this study have only been available for core- or intermediate-scale studies [Dong et al., 2002a; Morley et al., 1998; Murphy et al., 1997].

[5] To date, laboratory studies of bacterial transport have not successfully predicted field-scale bacterial transport [Harvey et al., 1993], making it difficult to design successful bioaugmentation strategies and/or assess threats to drinking water. One reason for this difficulty in scaling bacterial transport could be the fact that attachment rates have been observed to be greatest near the injection point and then decrease with travel distance both in laboratory and field-based studies [Albinger et al., 1994; Baygents et al., 1998; Bolster et al., 1999; DeFlaun et al., 1997; Dong et al., 2002a; Harvey et al., 1995; Simoni et al., 2000]. These analyses have indicated that at low ionic strengths the collision efficiency $(\alpha)$ within a monoclonal strain of bacteria may not be uniform [Albinger et al., 1994; Baygents et al., 1998; Bolster et al., 1999; Dong et al., 2002a; Fuller et al., 2000a; Glynn et al., 1998]. Capillary electrophoretic mobility data and microscopic studies indicate there may be distinct subpopulations (two- $\alpha$ model) within a laboratory grown culture [Glynn et al., 1998]. Modeling of core experiments indicates that injected bacterial strains may have a range of properties [Dong et al., 2002a] or distinct subpopulations [Albinger et al., 1994]. Regardless of the shape of the $\alpha$ distribution for a bacterial strain, high $\alpha$ cells will attach to sediments near the point of injection; whereas the bacteria with low $\alpha$ will account for the farfield transport.

[6] This paper investigates the role of aquifer and microbial heterogeneity on the transport of the adhesion deficient bacterium Comamonas sp. strain DA001 and the conservative tracer bromide $(\mathrm{Br})$ through a shallow coastal plain aquifer in Oyster, Virginia. The site has been well characterized by coupling tomographic geophysical surveys to hydrological and sedimentological analyses [Hubbard et al., 2001; Scheibe et al., 2001]. Results from tracking the coinjection of one bacterial strain and $\mathrm{Br}$ are presented. The analysis of the data focuses on relating the movement and attachment of the bacteria to the observed heterogeneity. Results indicate that variations in flow direction and velocity of the injected bacteria are observable but that differences in attachment rate are smaller than laboratory studies would predict. Intrapopulation variability in microbial properties most likely obfuscates the effect of aquifer heterogeneity and controls transport. Microbial heterogeneity observed during laboratory core studies could be used to predict field-scale transport when microbial heterogeneity was incorporated into colloid filtration theory.

\section{Methods}

\subsection{Field Site}

[7] This research was conducted at the Department of Energy (DOE)/Natural and Accelerated Bioremediation Research Program (NABIR) South Oyster Bacterial Transport Field Site located on the southern Delmarva Peninsula near the town of Oyster, Virginia (Figure 1). This is an intensely cultivated sandy lowland where the surficial deposits are part of the late Pleistocene Columbia Aquifer and consist of medium-grained quartz sands with some gravelly layers and small amounts of clays and silts [Richardson, 1994; Speiran, 1996]. The sediments at the site contain orange to brown coatings approximately a few microns thick, which transmission electron microscopy (TEM) and scanning electron microscopy (SEM) analyses indicate contain smectite, chlorite, goethite, halloysite, amorphous $\mathrm{Al}$, and amorphous Fe-bearing silica [Dong et al., 2002b; Zhu et al., 2000]. The Pliocene Yorktown Formation acts as an aquitard that forms the lower boundary 

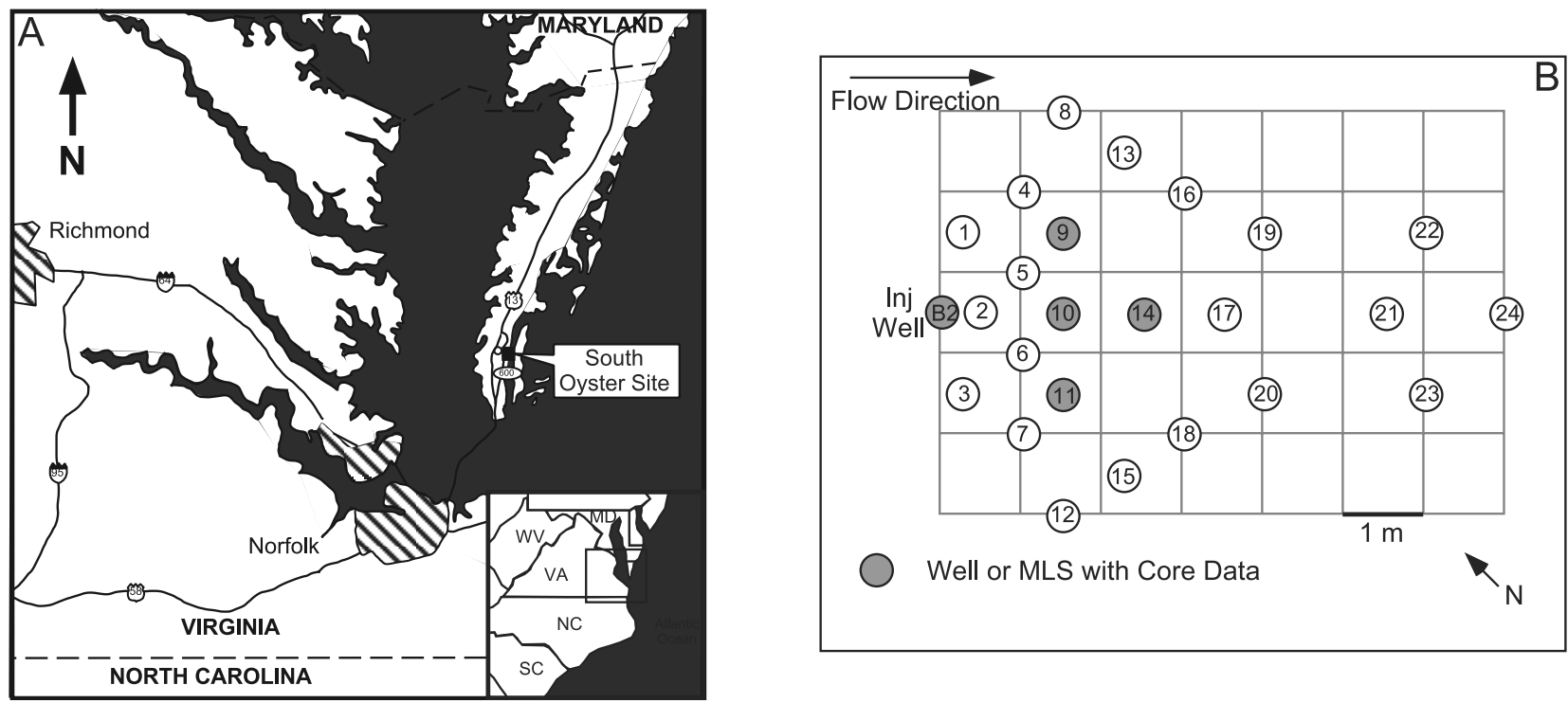

Figure 1. Site location and map of the study area at the Oyster Site. (a) The location of Oyster, Virginia, on the Eastern Seaboard of the United States. (b) The multilevel sampler layout and the location of injection well B2 on a $1 \mathrm{~m}$ grid. During installation, sediment cores were obtained from 5 MLSs by the roto-sonic drilling method (RD 150 Sonic Drill Rig, Boart Longyear, Little Falls, Minnesota). Each MLS has twelve $0.27 \mathrm{~m}$ sampling ports that are evenly spaced from -3 to $-6 \mathrm{~m} \mathrm{msl}(6-9 \mathrm{~m}$ bgs) [Mailloux, 2003]. Within NCFA, 14 other wells were screened from 0 to $-6 \mathrm{~m}$ msl (3.05-9.14 $\mathrm{m}$ bgs) and were used for monitoring water levels, creating the forced gradient, and monitoring far-field bacterial transport.

at a depth of approximately $-7 \mathrm{~m}$ mean sea level (msl) $(10$ $\mathrm{m}$ below ground surface (bgs)).

[8] Results are from a field injection of bacteria and $\mathrm{Br}$ conducted at the Narrow Channel Focus Area (NCFA) in October 1999. The characteristics of the site have been described by Hubbard et al. [2001]. The methods used to inject and sample the bacterial plume [Mailloux, 2003], to quantify bacterial concentrations [Fuller et al., 2001; Holben and Ostrom, 2000; Johnson et al., 2001], and to quantify the extended tailing and predation [Zhang et al., 2001] have been previously described.

[9] Characterization of the permeability and the grain size of the sediments was performed using the falling head method and sieve analysis, respectively, on five cores taken from NCFA (Figures 1 and 2) [Green et al., 2000]. Fe and $\mathrm{Al}$ oxyhydroxide content was determined using the citratebicarbonate-dithionite extraction method on the same cores [Dong et al., 2002a]. Fe and Al oxyhydroxide concentrations were corrected for $\mathrm{Fe}$ and $\mathrm{Al}$ derived from clays by determining the $\mathrm{Mg}$ concentration in the extracts and comparing it with the $\mathrm{Mg}$ content of clays as determined by TEM analysis. Porosity was estimated from three $\mathrm{Br}$ injections conducted in July and August 1999 [Scheibe et al., 2001].

[10] Samples were collected throughout the experiment for water chemistry. Samples for $\mathrm{pH}$, dissolved oxygen, conductivity, and temperature were measured in the field with a Horiba U-10 (Cole Parmer, Vernon Hills, Illinois). Anion and cation samples were collected for analysis by filtering through a $0.45 \mu \mathrm{m}$ filter (Pall Gelman, Ann Arbor, Michigan), cation samples were fixed with nitric acid, and both samples were analyzed by Actilabs (Ancaster, Ontario, Canada). Samples for total organic carbon (TOC) and dissolved organic carbon (DOC) were collected in $40 \mathrm{~mL}$
I-Chem glass vials with no headspace, sealed with a Teflon lined silicone septa, fixed with $0.2 \mathrm{~mL}$ of $6 \mathrm{~N} \mathrm{HCl}$, and analyzed by Envirogen, Inc. (Lawrenceville, New Jersey).

\subsection{Bacterial Injection}

[11] A forced gradient imposed across the flow field produced an average flow velocity of $1 \mathrm{~m} / \mathrm{d}$ directed down the flow axis [Scheibe et al., 2001]. A solution of $\mathrm{NaBr}$ and bacteria was injected into well B2 for 12 hours at a rate of $1 \mathrm{~L} / \mathrm{min}$ between -4.8 to $-5.3 \mathrm{~m} \mathrm{msl}$ (approximately at the level of ports 8 and 9). This depth corresponds to a lens of high hydraulic conductivity (Figure 3 ). The bacteria utilized were adhesion deficient variants of Comamonas sp. strain DA001, which is a nonmotile, hydrophilic, rod-shaped, gram-negative bacterium approximately $1 \mu \mathrm{m}$ long and $0.5 \mu \mathrm{m}$ wide. It has a near neutral surface charge with a zeta potential of approximately $-6.0 \times 10^{-9} \mathrm{~m}^{2} / \mathrm{Vs}$ and a density of approximately $1.06 \mathrm{~g} / \mathrm{cm}^{3}$ [Dong et al., 2002a]. The bacteria were stained with the vital fluorescent stain 5(and-6-)-carboxyfluorescein diacetate succinimidyl ester (CFDA/SE). This stain has been shown not to alter the adhesion characteristics or viability of the bacteria, while remaining in the cells for extended periods of time [Fuller et al., 2000b].

[12] Samples were collected from ports 5-12 of the 24 multilevel samplers (MLSs) in $50 \mathrm{~mL}$ centrifuge tubes and fixed with formaldehyde ( $1 \%$ final concentration vol/vol) [Fuller et al., 2001]. Bacterial concentrations were determined by flow cytometry at the Flow Cytometry Core Facility at Princeton University on a FACScan instrument (Becton Dickinson Immunocytometry Systems, San Jose, California) [Fuller et al., 2000b]. The enumeration of injected bacteria by flow cytometry has been shown to produce results consistent with numerous other tracking 
Inj Well B2

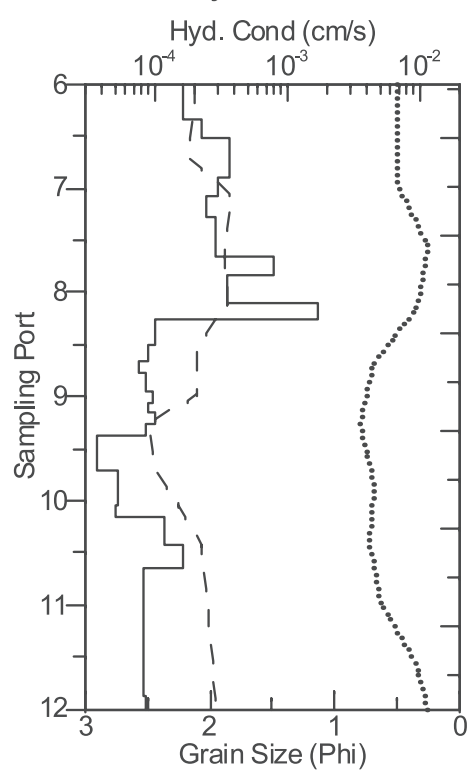

S10

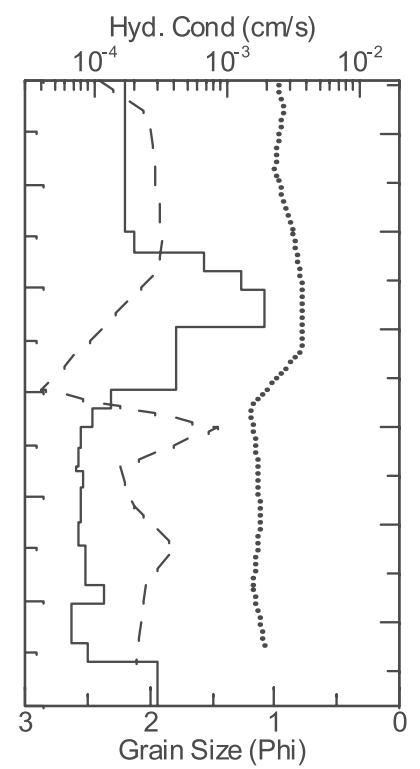

S14

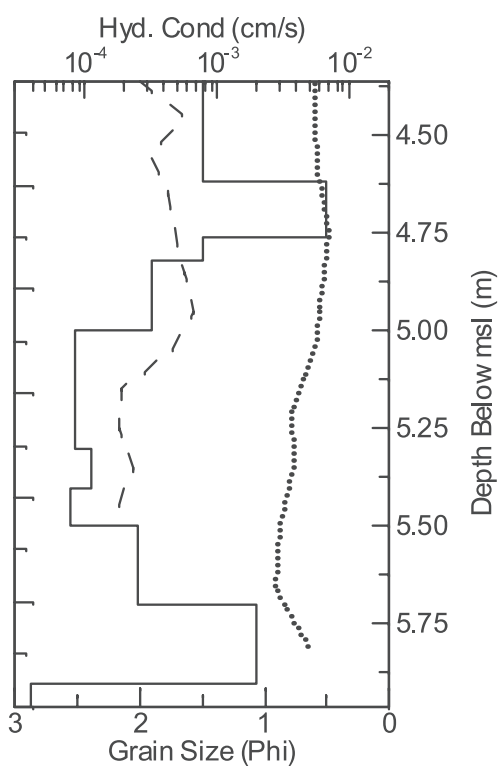

S11

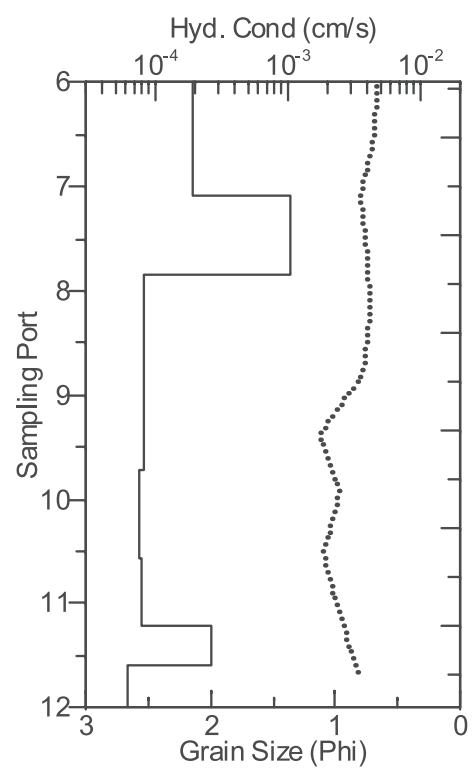

S9

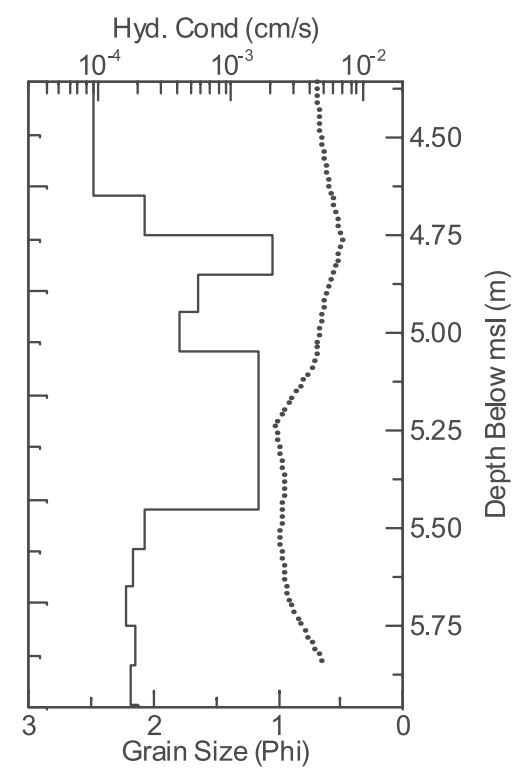

Grain Size (Phi)

Falling Head K (cm/s)

\section{Field Test and Flowmeter K $(\mathrm{cm} / \mathrm{sec})$}

Figure 2. Sedimentological data from cores taken within the MLS array. The figure shows data from cores located parallel to the flow axis from the injection well NC-B2 to S14 and the data from cores S9 and S11 located perpendicular to the flow axis (Figure 1b). The data are presented in terms of mean grain size diameter in phi $(-\log 2(\mathrm{~mm}))$. Slug tests were conducted at 12 wells at NCFA, and the hydraulic conductivity was estimated by the Bouwer and Rice method [Freeze and Cherry, 1979]. A pump test was conducted with NC-B2 pumping at a rate of $64 \mathrm{~L} / \mathrm{min}(17 \mathrm{gpm})$ and pressure transducers located in 10 wells. The results were interpreted utilizing the Neuman method for unconfined aquifers [Freeze and Cherry, 1979]. The relative hydraulic conductivity of 11 boreholes was measured using an electromagnetic borehole flowmeter (Quantum Engineering Corporation, Loudon, Tennessee). Relative hydraulic conductivities were converted into true hydraulic conductivities using the average hydraulic conductivity values from the slug tests and pump test. 

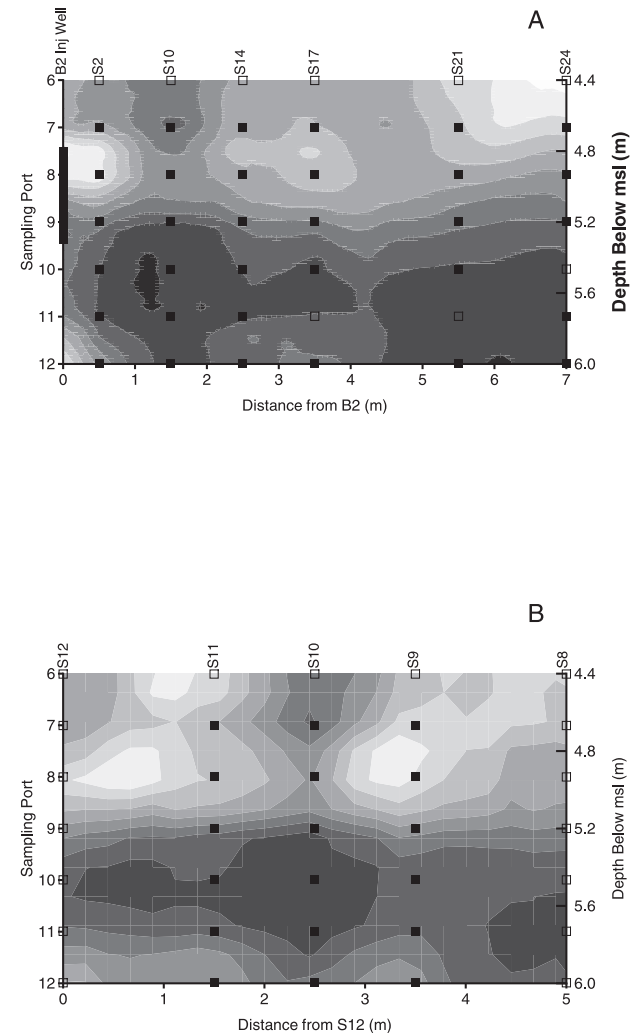

Figure 3. Geophysical estimates from radar tomography of hydraulic conductivity across the zone of the bacterial injection. A Bayesian approach, utilizing the slug test and flowmeter data as prior information, was followed to estimate the hydraulic conductivity from the tomographically mapped radar velocities for two cross sections [Chen et al., 2001; Hubbard et al., 2001]. (a) Cross section parallel to the flow axis. (b) Cross section perpendicular to the flow axis. The left vertical axis is the depth in terms of the sampling port, and the right axis indicates the depth below mean sea level, in meters. The injection zone was located from 4.8 to $5.3 \mathrm{~m}$ below ground surface and is represented by a solid line in Figure $3 \mathrm{a}$. Solid squares indicate MLS ports where significant breakthrough was observed; open squares indicate MLS ports where no breakthrough was observed.

methods [DeFlaun et al., 2001; Fuller et al., 2001; Johnson et al., 2001]. Br concentrations were determined with an ion selective $\mathrm{Br}$ probe (Cole-Parmer, Vernon Hills, Illinois) connected to a Corning $\mathrm{pH} /$ ion analyzer (Corning, Inc., Corning, New York).

\subsection{Intact Sediment Core Experiments}

[13] Laboratory column experiments utilized $0.5 \mathrm{~m}$ intact sediment cores collected from an excavation located approximately $100 \mathrm{~m}$ south-southwest from the NCFA flow cell [Dong et al., 2002a]. The intact core experiments were specifically designed to mimic the field-scale experiment. Two cores, designated NC8-1SAT and NC12-1SAT, were collected parallel to the direction of groundwater flow from just below the water table. The experiments were conducted under saturated conditions at $15^{\circ} \mathrm{C}$ utilizing groundwater collected from injection well B2 and at flow velocities of
$1.0 \mathrm{~m} / \mathrm{d}$ [Dong et al., 2002a; Fuller et al., 2000a]. DA001 grown on ${ }^{14} \mathrm{C}$ acetate was injected at concentrations similar to that used in the field experiment, and its breakthrough was monitored for 7 days. Carbon 14 analyses of subsamples from the core were used to determine sorbed bacterial concentrations, and SEM was utilized to determine grain size, grain coatings, and porosity.

\subsection{Numerical Analysis}

[14] The bacterial and $\mathrm{Br}$ breakthrough curves for each port were parameterized for comparison to the aquifer properties and for estimation of microbial heterogeneity using colloid filtration theory. The total mass or zeroth moment observed at a given port was calculated by trapezoidal integration of the breakthrough curve. The first moment $\left(t_{1 / 2}\right)$ was defined as the time when the cumulative mass that has broken through reaches half the total mass [Turner, 1972]. This location was linearly interpolated from the two nearest neighbor data points on either side of the halfway point.

[15] The bacterial attachment was parameterized by the relative breakthrough $(\mathrm{RB})$, which compares the zeroth moments of the bacteria to the $\mathrm{Br}$. The RB is [Harvey and Garabedian, 1991]

$$
R B=\frac{\frac{\int_{0}^{\infty} C_{i}^{\text {cell }} d t}{C_{o}^{\text {cell }}}}{\frac{\int_{0}^{\infty} C_{i}^{B r} d t}{C_{o}^{B r}}}
$$

All symbols are defined in Table 1. Near the injection well where little bacterial attachment has occurred, RB should be slightly less than one. RB decreases with distance from the injection well, until all the bacteria have attached to the sediment and RB equals zero.

[16] The longitudinal dispersivity $\left(\alpha_{l}\right)$ was calculated as a means of comparing the amount of heterogeneity encountered in the field with the heterogeneity encountered during intact column experiments [Dong et al., 2002a]. The dispersivity was calculated utilizing the method from Turner [1972]:

$$
\begin{aligned}
\sigma^{2} & \left.=\left(\frac{\int_{0}^{\infty} c_{i} t_{i}^{2} d t}{\left.\int_{0}^{\infty} c_{i} d t\right)-\left(\int_{0}^{\infty} c_{i} t_{i} d t\right.}\right)^{2} c_{0}^{\infty} c_{i} d t\right) \\
P e & =\frac{\left[\left(1+\frac{8 \sigma^{2}}{\left(1 / t_{1 / 2}\right)^{2}}\right)^{1 / 2}+1\right]}{\sigma^{2} /\left(1 / t_{1 / 2}\right)^{2}}=\frac{x}{\alpha_{l}}
\end{aligned}
$$

The second moment $\left(\sigma^{2}\right)$ represents the spread in the data around the first moment and can be related to the longitudinal dispersivity $\left(\alpha_{l}\right)$ through the Peclet $(P e)$ 
number. The distance to each $\operatorname{MLS}(x)$ was taken as the longitudinal distance from injection well NC-B2 plus one half the lateral distance. Horizontal flow was assumed. This is only an approximation to the flow distance to the offcenter wells since the fluid flow equation would need to be solved to obtain the amount of radial flow away from injection well.

[17] The collision efficiency $(\alpha)$ for the injected bacteria at each sampling port was calculated from the RB using the following expressions from colloid filtration theory [Harvey and Garabedian, 1991; Logan et al., 1995; Rajagopalan and Tien, 1976]:

$$
\begin{gathered}
R B=\exp \left[-\frac{3}{2} \frac{(1-\theta)}{d_{c}} \alpha \eta x_{i}\right]=\exp [-\alpha \xi] \text { or } \alpha=-\frac{\ln (\mathrm{RB})}{\xi} \\
\eta=4 A_{s}^{1 / 3} N_{P e}^{-2 / 3}+A_{s}^{1 / 3} N_{L o}^{1 / 8} N_{R}^{15 / 8}+0.00338 A_{s} N_{G}^{1.2} N_{R}^{-0.4} \\
A_{s}=\frac{2\left(1-\gamma^{5}\right)}{2-3 \gamma+3 \gamma^{5}-2 \gamma^{6}} \gamma=(1-\theta)^{1 / 3} \\
N_{\mathrm{Pe}}=\frac{6 \pi \mu \mathrm{a}_{\mathrm{b}} \nu \theta d_{c}}{k T} \\
N_{l o}=\frac{H}{9 \pi \mu a_{b}^{2} \nu \theta} \\
N_{R}=\frac{2 a_{b}}{d_{c}}
\end{gathered}
$$

and

$$
N_{G}=\frac{2 g\left(\rho_{b}-\rho_{f}\right) a_{b}^{2}}{9 \mu \nu \theta}
$$

Equations (4)-(10) account for removal by diffusion $\left(N_{P e}\right)$, interception $\left(N_{R}\right)$, and gravitational sedimentation $\left(N_{G}\right)$. Equation (4) can only be utilized when $\alpha_{l} / x_{I}$ is less than 0.01 , which was tested by equation (3) and always found valid. The fluid velocity was calculated utilizing the first moment of the Br breakthrough curve.

[18] The grain size $d_{c}$ was derived from the grain size data from five cores. The data were vertically averaged for each of the five cores to compute a grain size for each sampling port. The grain size data obtained from cores collected at the injection well was assumed to be directly transferable to S2 due to its proximity and the similarities in the geophysical estimates of hydraulic conductivity. The grain size for each port of the remaining 19 MLSs for which there were no cores, was calculated with an inverse distance algorithm that utilized the grain size data derived for the equivalent ports of the five cores. When assuming a

\begin{tabular}{|c|c|}
\hline Parameter & Description \\
\hline$t$ & time, ${ }^{a}$ hours or seconds \\
\hline$C_{i}^{\text {cell }}, C_{i}^{B r}$ & bacterial (cells $/ \mathrm{mL})$ and $\mathrm{Br}(\mathrm{mg} / \mathrm{L})$ concentration $^{\mathrm{a}}$ \\
\hline$C_{o}^{\text {cell }}, C_{o}^{B r}$ & injected bacterial (cells $/ \mathrm{mL})$ and $\mathrm{Br}(\mathrm{mg} / \mathrm{L})$ concentration $^{\mathrm{a}}$ \\
\hline$v_{I}$ & fluid velocity to $i$ th observation location ${ }^{\mathrm{a}}$ \\
\hline$x_{I}$ & distance, ${ }^{\mathrm{a}} \mathrm{m}$ \\
\hline$\sigma^{2}$ & second moment $(-)$ \\
\hline$\alpha_{l}$ & longitudinal dispersivity, ${ }^{\mathrm{a}} \mathrm{m}$ \\
\hline$R B$ & relative breakthrough ${ }^{\mathrm{a}}(-)$ \\
\hline$\theta$ & porosity $^{\mathrm{b}}(-)$ \\
\hline$\alpha$ & collision efficiency ${ }^{\mathrm{c}}(-)$ \\
\hline$\eta$ & collector efficiency $^{\mathrm{a}}(-)$ \\
\hline$\xi$ & filtration distance ${ }^{a}(-)$ \\
\hline$d_{c}$ & collector diameter, ${ }^{a} \mathrm{~m}$ \\
\hline$A_{s}$ & Happel correction factor ${ }^{\mathrm{c}}(-)$ \\
\hline$N_{P e}$ & bacterial Peclet number ${ }^{\mathrm{c}}(-)$ \\
\hline$N_{L o}$ & dimensionless London-van der Waals forces ${ }^{\mathrm{c}}(-)$ \\
\hline$N_{R}$ & interception number ${ }^{\mathrm{c}}(-)$ \\
\hline$N_{G}$ & gravitation number $^{\mathrm{c}}(-)$ \\
\hline$\gamma$ & porosity parameter ${ }^{\mathrm{c}}(-)$ \\
\hline$a_{b}$ & radius of bacteria, ${ }^{\mathrm{d}} 0.5 \times 10^{-6} \mathrm{~m}$ \\
\hline$\mu$ & viscosity of water, $1.14 \times 10^{-3} \mathrm{Ns} / \mathrm{m}^{2}$ \\
\hline$K$ & Boltzmann's constant, $1.38 \times 10^{-23} \mathrm{kgm}^{2} / \mathrm{s}^{2} / \mathrm{K}$ \\
\hline$T$ & temperature, ${ }^{\mathrm{a}} 287^{\circ} \mathrm{K}$ \\
\hline$H$ & Hamaker constant, ${ }^{\mathrm{d}} 1 \times 10^{-20} \mathrm{~J}$ \\
\hline$G$ & gravitational constant, $9.8 \mathrm{~m} / \mathrm{s}^{2}$ \\
\hline$\rho_{b}$ & density of bacteria, ${ }^{\mathrm{d}} 1060 \mathrm{~kg} / \mathrm{m}^{3}$ \\
\hline$\rho_{f}$ & density of water, $1000 \mathrm{~kg} / \mathrm{m}^{3}$ \\
\hline$P_{G}$ & Gaussian probability function $(-)$ \\
\hline $\mathrm{SD}$ & standard deviation $(-)$ \\
\hline $\operatorname{Var}_{p}$ & variability in a parameter $(-)$ \\
\hline$V a l_{p}$ & value of a parameter \\
\hline $\operatorname{Avg}$ & average value of a parameter \\
\hline
\end{tabular}
constant sediment density with grain size, the number weighted and mass weighted averages for grain size were nearly identical (data not shown).

[19] The $\alpha$ distribution of DA001 cells injected into 50 $\mathrm{cm}$ intact sediment cores was calculated from the profile of
Table 1. Notation for Equations in Text

${ }^{a}$ Values derived from field experiment

${ }^{\mathrm{b}}$ Values from Scheibe et al. [2001].

${ }^{\mathrm{c}}$ Calculated from data.

${ }^{\mathrm{d}}$ Values from Dong et al. [2002a].

bacteria sorbed to the sediment at the millimeter scale along the length of each column. The calculated $\alpha$ distribution only accounted for the subset of bacteria that sorbed to the sediments, which was $42 \%$ and $33 \%$ of the injected bacteria for cores NC8-1 and NC12-1, respectively. The average $\alpha$ was taken as the average of all the calculated $\alpha$ along the length of the core.

[20] A lognormal $\alpha$ distribution and a two- $\alpha$ model are used to attempt to explain the observed $\alpha$ distribution at the field scale and predict the observed RB. The $\alpha$ distribution calculated from the field experiment represents a large percentage of the injected population because $\mathrm{RB}$ at $7 \mathrm{~m}$ was 0.07 . The mean and standard deviation (SD) of the $\alpha$ distribution was directly inferred and weighted by the number of sampling ports. Since the intact core data represent only a portion of the bacterial population, the mean and standard deviation of the total bacterial distribution, weighted by the number of sorbed bacteria, could not be directly calculated. To estimate a lognormal distribution, core-derived partial $\alpha$ distributions were fit using a Gaussian probability function with log transformed values [Bevington and Robinson, 1992]:

$$
P_{G}(\alpha: \bar{\alpha}, S D)=\frac{1}{\log (S D) \sqrt{2 \pi}} \exp \left[-\frac{1}{2}\left(\frac{\log (\alpha)-\log (\bar{\alpha})}{\log (S D)}\right)^{2}\right]
$$


The fitting procedure assumed that the sorbed population represents the upper percentiles in the $\alpha$ distribution and the bacteria eluted from the core represent the lower percentiles. The manual fitting procedure utilized only the sorbed data and minimized the observed (observed value calculated value) and the absolute value of the observed error. The area under the fitted portion of the probability curve matched the percent sorbed. This method ensured that the probability curve was systematically fit to the limited sampling population that the sorbed data represent. The calculated $\alpha$ distribution was then utilized in equation (4) to predict RB at different distances in the field. The $\alpha$ distribution was divided into 39 log-interval bins with values that ranged from $10^{-9}$ to $10^{0}$, the majority of these bins bracketed the mean $\alpha$ producing a smooth distribution. Equation (9) was then multiplied by the width of the bin to convert from the probability function to the fraction of the total population represented by each bin. Equation (4) was solved for RB using the $\alpha$ from each bin at every distance of interest. The resulting RB values were then multiplied by the calculated fraction of the injected bacterial population possessing the given $\alpha$ from equation (9). This produced an estimate of the contribution of each bacterial subpopulation to the total RB. Each subpopulation was summed to obtain the predicted $\mathrm{RB}$ at each distance for the given $\alpha$ distribution.

[21] In the two- $\alpha$ model, two distinct populations were assumed present in the injected bacteria. Calculating the $\alpha$ at a distance from the injection point may smear the two distinct peaks because the observed $\alpha$ value has become averaged over the travel distance. The $\alpha$ values therefore have to be back-calculated from distances representative of every sampling port. The high $\alpha$ value, the low $\alpha$ value, and fraction of high versus low were chosen first. The RB versus distance was then calculated with equation (4) for each fraction and summed. Then at a distance representative of a sample, the observed $\alpha$ was calculated using the summed RB. The calculated $\alpha$ were then utilized to create an $\alpha$ distribution. The calculated distribution was then compared with the observed distribution to fit the data. The manual fitting method tried to fit the core and field $\alpha$ data while also predicting the RB from the field data.

\subsection{Error Analysis}

[22] An estimate of the expected error in the calculated $\mathrm{RB}$ was determined given the error in measuring $\mathrm{Br}$ and bacterial concentrations and the limited number of sampling points spaced across each breakthrough curve. A sensitivity analysis utilizing the one-dimensional advection-dispersion equation was conducted to determine the number of data points required to accurately record a breakthrough event. Six data points spread throughout a breakthrough curve, with one or two values near the peak, were found to give estimates of the first moment to within $8 \%$ of the true value when utilizing trapezoidal integration (data not shown). For all samples with concentrations above $1 \times 10^{4}$ cells $/ \mathrm{mL}$ collected during this injection, the arithmetic and geometric mean of the relative uncertainty (taken as the standard deviation divided by the mean and multiplied by 100) were $13 \%$ and $4 \%$, respectively. For error propagation calculations, all flow cytometry samples were assumed to have an error of $8 \%$ and $\mathrm{Br}$ samples had an error of $2 \%$ [ColeParmer, 2000]. The corresponding average and median of the percent error in the calculated RB were $19 \%$ and $8 \%$, respectively.

\subsection{Effect of Heterogeneity}

[23] The controls on bacterial transport were determined by comparing horizontal and vertical variations between two parameters. Normalized variation around a mean was defined as

$$
\operatorname{Var}_{p}=\frac{\operatorname{Val}_{p}-A v g}{A v g}
$$

For horizontal variability (Var), the symmetric ports across the centerline were compared (e.g., S9p8 and S11p8) with the average taken from the two values. For vertical variability the ports at each sampler were compared with the average taken as the average of the six values of $\mathrm{p} 7-12$. Plotting the variability of two parameters against each other can then illustrate if the two parameters are correlated. For example, if flow velocity increases with increases in permeability, a positive correlation would be expected between the two variables.

\section{Results}

\subsection{Observed Physical Heterogeneity}

[24] Slug and pump test data yielded average hydraulic conductivity values of $5.3 \pm 1.2 \times 10^{-3}$ and $3.9 \pm 1.6 \times$ $10^{-3} \mathrm{~cm} / \mathrm{s}$, respectively. The geophysical, flowmeter, and falling head data indicated that hydraulic conductivity varied by about 1 order of magnitude across the flow cell (Figures 2 and 3) [Chen et al., 2001; Hubbard et al., 2001]. Along the flow axis, the interval above $\mathrm{p} 9$ generally had the highest hydraulic conductivity (Figures 2 and $3 a$ ). Below p9 hydraulic conductivity decreases with depth down to $\mathrm{p} 11$, and sometimes increases at p12. The conductivity of the underlying Yorktown aquitard is not shown because the wells were terminated at the contact. The area of lowest conductivity is between S2 and S10 at p10 and p11. The conductivity of S10 at all ports is lower then both the upand down-gradient MLSs. These trends are also observed in the sedimentological and flowmeter data, which illustrate the highest conductivity and largest grain size near $\mathrm{p} 8$, and a decrease with depth before increasing near p12.

[25] The geophysical data perpendicular to the flow field also exhibit horizontal and vertical variations in conductivity. The zones of high conductivity are located between S9 and $\mathrm{S} 10$ and between $\mathrm{S} 11$ and S12 from $\mathrm{p} 7$ to $\mathrm{p} 9$. The area along the centerline near S10 appears to be a zone of lower conductivity. The hydraulic conductivity decreases below p9, with the zone of lowest conductivity on the southwest side of the flow cell from S10 to S12 at p10 and p11. These trends are also evident in the sedimentological and flowmeter data. The grain size data indicate that S11 p10 and p11 have the smallest grain size measured in the flow cell. In summary, a lens of low conductivity is located on the southwest side of the flow cell from S10 to S12 at p10 and p11 and is not as prevalent on the northeast side of the flow cell.

[26] The amount of $\mathrm{Fe}$ and $\mathrm{Al}$ oxyhydroxide was measured using the $\mathrm{Na}$ dithionite method for 19 samples within the transport zone representing 12 separate sampling ports [Dong et al., 2002a]. The Fe and Al oxyhydroxide concentration varied across the site with average values of $489 \pm$ 154, and $847 \pm 349$ ppm, respectively. The oxyhydroxides were inversely correlated with grain size, with the smallest 


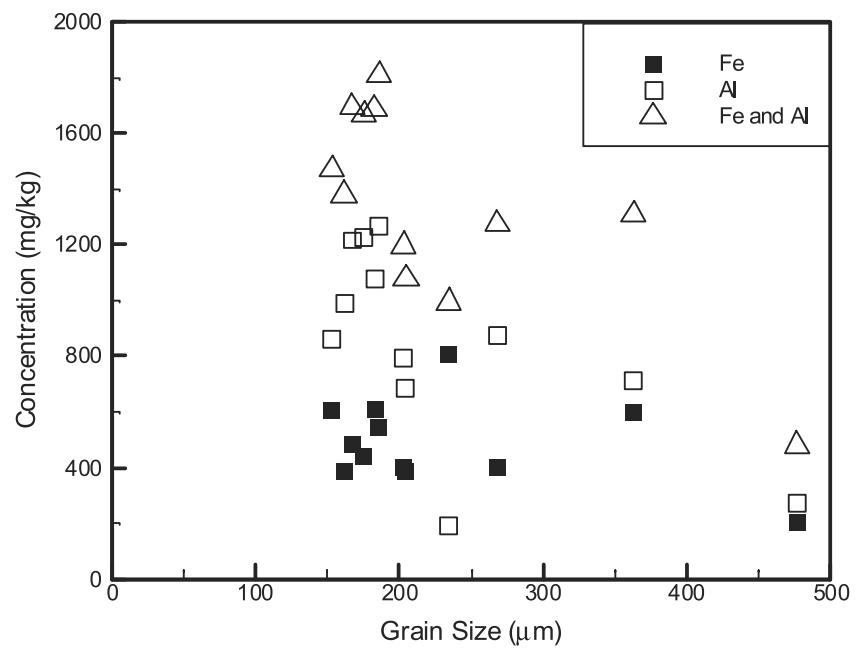

Figure 4. Grain size (microns) versus $\mathrm{Fe}$ and $\mathrm{Al}$ oxyhydroxides $(\mathrm{mg} / \mathrm{kg})$.

grain sizes yielding the highest concentrations of oxyhydroxides (Figure 4). The correlations with grain size were Fe, $-0.36, \mathrm{Al},-0.65$, and the sum of $\mathrm{Fe}$ and $\mathrm{Al},-0.75$.

\subsection{Bacterial Injection}

[27] The average $\mathrm{Br}$ and bacterial injection concentrations were $85.5 \pm 5.6 \mathrm{mg} / \mathrm{L}$ and $1.36 \pm 0.19 \times 10^{8}$ cells $/ \mathrm{mL}$. The average chemical parameters of the injectate were similar to that of the in situ groundwater [Mailloux, 2003]. The groundwater chemistry across the site during the experiment was relatively uniform. The average concentrations ( $\mathrm{mM})$ of the major constituents were dissolved $\mathrm{O}_{2}, 0.13 \pm 0.03$; ionic strength, $3.06 \pm 0.71$; total organic carbon, $0.63 \pm 0.14$; dissolved organic carbon, $0.46 \pm 0.09 ; \mathrm{Cl}, 0.67 \pm 0.13 ; \mathrm{NO}_{3}$, $0.52 \pm 0.09 ; \mathrm{SO}_{4}, 0.34 \pm 0.10 ; \mathrm{Na}, 0.63 \pm 0.04 ; \mathrm{Mg}, 0.18 \pm$ 0.07 ; Si, $0.16 \pm 0.02 ; \mathrm{K}, 0.06 \pm 0.01 ; \mathrm{Ca}, 0.65 \pm 0.20$; Fe, $0.003 \pm .0008 ; \mathrm{pH}, 5.86 \pm 0.18 ;$ and conductivity, $0.267 \pm$ $0.043 \mu \mathrm{S}$. No clumping of cells was observed in the injectate. At S2, located $0.5 \mathrm{~m}$ down-gradient, bacterial concentrations close to $10 \%$ of the injected values were observed 2 hours after the injection began (Figure 5). At $\mathrm{S} 10$, located $1.5 \mathrm{~m}$ down-gradient, significant bacterial concentrations were observed within 13 hours (Figure 5). Although the bacteria and $\mathrm{Br}$ were injected into the highpermeability zone corresponding to $\mathrm{p} 8$ and $\mathrm{p} 9$ of the samplers, the injectate plume was observed in $\mathrm{p} 7$ through p12, but not at p5 or p6 (Figures 5, 6, and 7). The injection of water above but not below the packered zone most likely created a vertical gradient that caused the injectate to migrate downward along the more permeable collapse zone around the outside of the casing of well NC-B2. Since bacteria and $\mathrm{Br}$ were not present above $\mathrm{p} 7$, only data from p7 through p12 are shown. For the rest of the analysis the data are treated assuming that no vertical transport occurred and the injection was across the zone from $\mathrm{p} 7$ to $\mathrm{p} 12$.
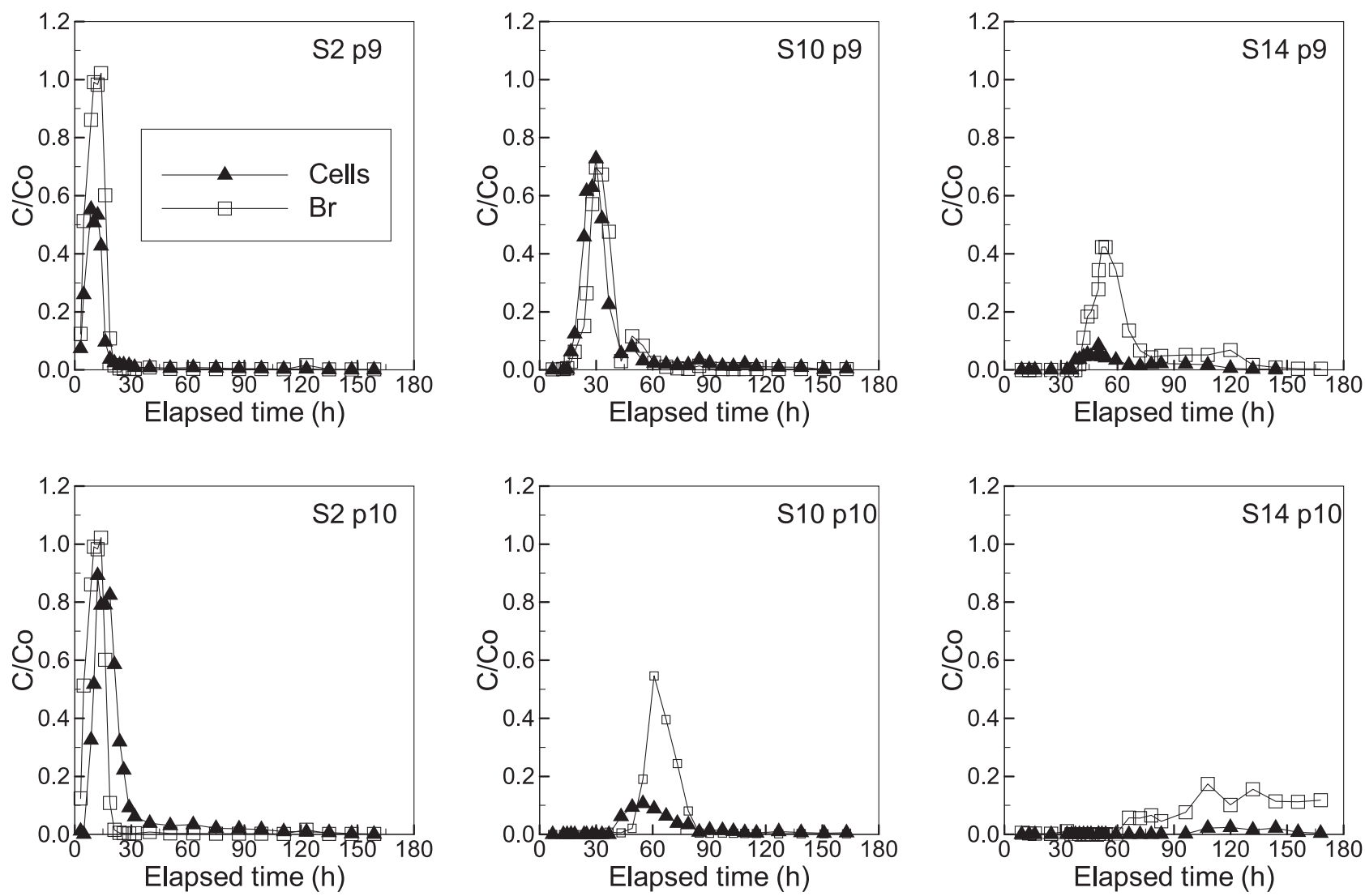

Figure 5. Breakthrough curves for $\mathrm{Br}$ and bacteria reported as dimensionless concentrations for $\mathrm{S} 2$, $\mathrm{S} 10$, and S14 at p9 and p10. The data from the rest of sampling ports are represented as time to center of mass (first moment) and RB in Figures 6 and 7. 

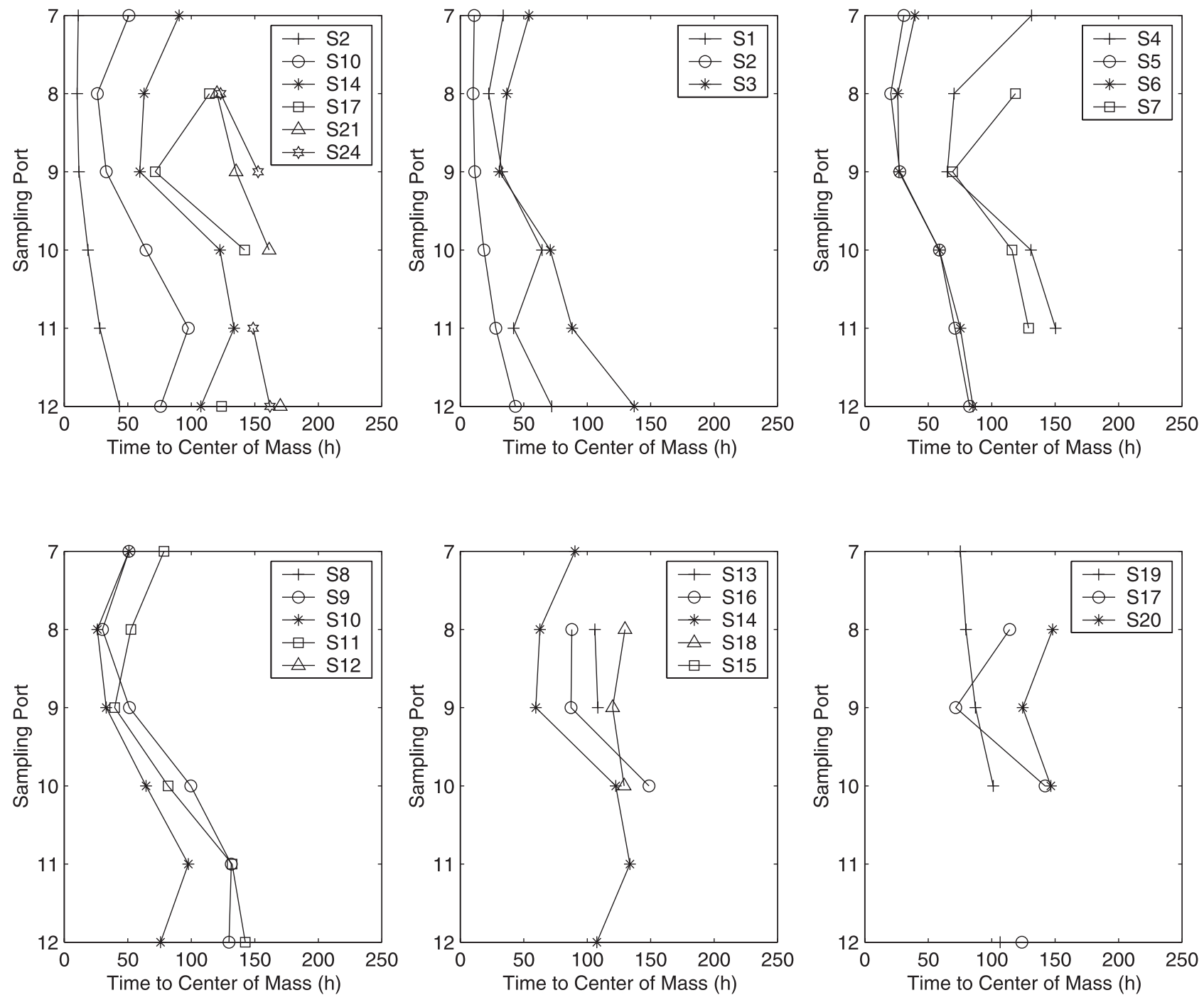

Figure 6. First moment of DA001 at each sampling location. If RB was insignificant for a port, no data are shown from that port. The data are shown down the flow axis and grouped by MLSs symmetrically spaced with respect to the flow axis. For some wells, data from the slower ports were not available because sampling did not continue long enough (e.g., S17, S21, and S24). No breakthrough was observed at S8 and S12.

[28] Breakthrough curves with bacteria and $\mathrm{Br}$ were collected at 95 sampling ports. The following samples were removed from the data set because they were anomalous when compared with samples collected immediately prior to or after they were collected: S1 at 114 hours, S16 at 62.75 hours, S3 at 103 hours, S18 at 103.85 hours, and S19 at 101.94 hours. The 37 missing data points resulting from lost or empty bottles were replaced with a linear average of the nearest neighbor data.

[29] DA001 breakthrough was always accompanied by $\mathrm{Br}$ breakthrough, indicating that both tracers followed similar flow paths. During the injection, the plume was observed in all MLSs except S8, S12, and S15. The breakthrough curves indicate that the peak concentrations of $\mathrm{Br}$ and DA001 generally decreased down-gradient (Figures 5 and 7). In addition, the peak concentration of DA001 usually decreased faster than the concentration of Br. There also appeared to be zones where very little attachment of DA001 occurred (e.g., S2 p10 and S10 p9). The amount of
DA001 breakthrough tended to decrease with depth, with more breakthrough occurring at p9 than p10 (Figures 5 and 7). In addition, it appeared that DA001 arrived slightly ahead of the $\mathrm{Br}$ at a limited number of ports (e.g., S10 p10) and slightly later than $\mathrm{Br}$ at other ports (e.g., S2 p10) (Figure 5).

[30] The first moment at each sampling port was similar for both the Br and DA001 breakthrough data, and therefore only the DA001 data are shown (Figure 6). The results are reported as time to center of mass without conversion to velocity because the flow distance to the off-axis wells is not precisely known. The results indicate a distinct pattern with depth in which $\mathrm{p} 8$ and $\mathrm{p} 9$ consistently had the fastest travel times, p11 usually had the slowest, and p12 was faster or slower than p11 depending on location. The first moments of DA001 and the geophysical estimates of hydraulic conductivity were correlated (Table 2, Figure 8).

[31] The dispersivity values for $\mathrm{Br}$ ranged from less than 0.01 to greater than $0.1 \mathrm{~m}$ with an arithmetic mean of 

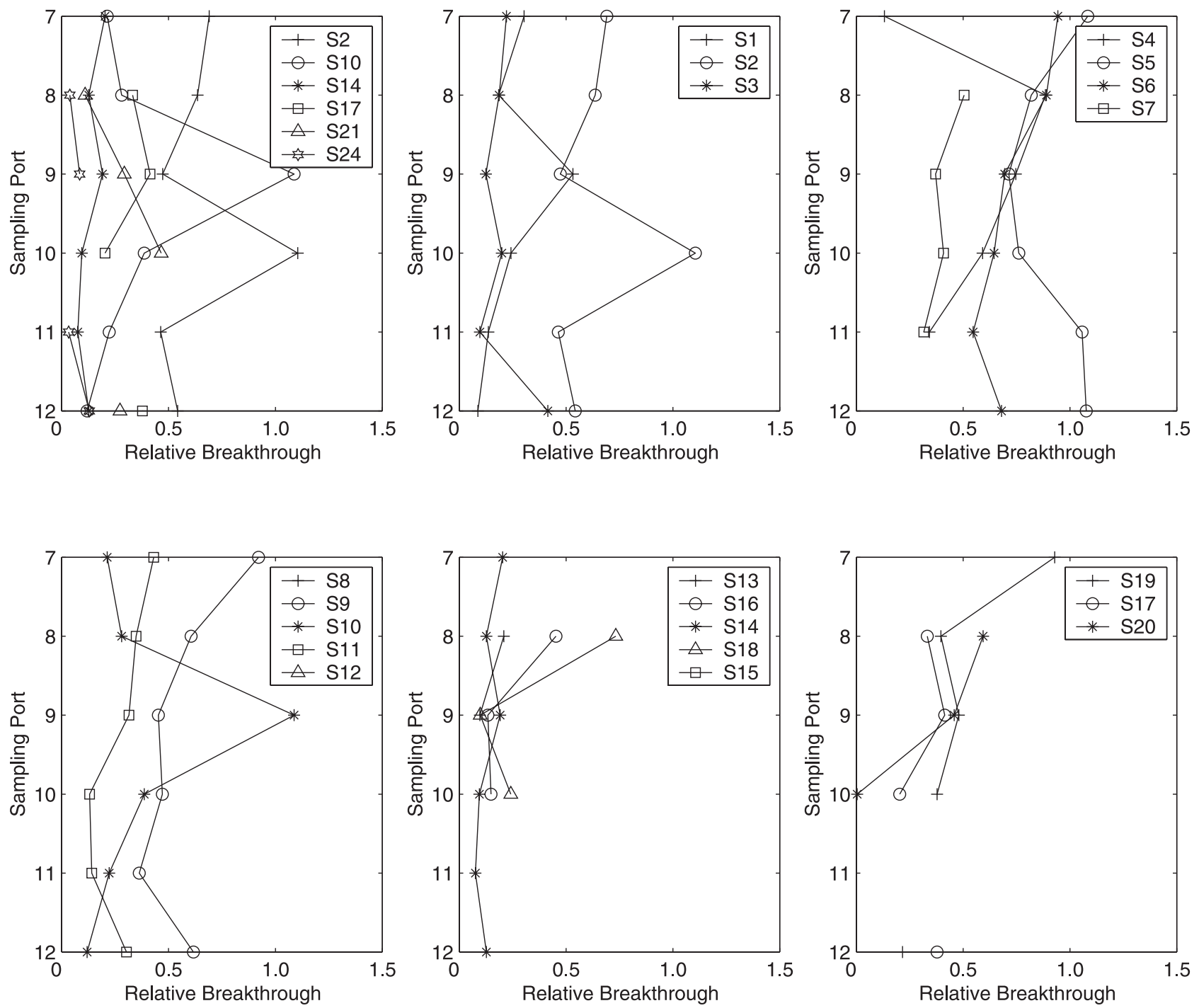

Figure 7. The RB of DA001 at each sampling location. If RB was insignificant for a port, no data are shown from that port. The data are shown down flow axis and grouped by MLSs symmetrically spaced with respect to the flow axis.

$0.06 \mathrm{~m}$. No clear trend in the data with time or distance was detected with all correlations with site data below 0.3 (data not shown). These values of dispersivity were slightly greater than the average value of $0.01 \mathrm{~m}$ obtained for 0.5 $\mathrm{m}$ intact core experiments run in the laboratory [Dong et al., 2002a], but less than values obtained for larger-scale field injections conducted at Cape Cod [Garabedian et al., 1991].

[32] RB for DA001 tended to decrease with distance from the injection well, with S2, the closest sampler, ranging from 0.5 to 1.0 and values of less than 0.1 observed in some ports of the more distant samplers (Figures 7 and 9). The

Table 2. Correlations Between Vertical Variations in DA001 RB, First Moment, Hydraulic Conductivity, Collision Efficiency, Fe + Al, and $\mathrm{Al}$ Oxyhyroxides Observed at Each MLS ${ }^{\mathrm{a}}$

\begin{tabular}{|c|c|c|c|c|c|c|}
\hline & $\mathrm{RB}$ & First Moment & Hydraulic Conductivity ${ }^{\mathrm{b}}$ & Collision Efficiency & $\mathrm{Fe}+\mathrm{Al}^{\mathrm{c}}$ & $\mathrm{Al}$ \\
\hline $\mathrm{RB}$ & 1.00 & -0.27 & 0.10 & -0.48 & 0.53 & 0.61 \\
\hline First Moment & -0.27 & 1.00 & -0.50 & -0.33 & 0.12 & 0.17 \\
\hline Hydraulic Conductivity ${ }^{\mathrm{a}}$ & 0.10 & -0.50 & 1.00 & 0.37 & -0.17 & 0.01 \\
\hline Collision Efficiency & -0.48 & -0.33 & 0.37 & 1.00 & -0.36 & -0.63 \\
\hline $\mathrm{Fe}+\mathrm{Al}^{\mathrm{c}}$ & 0.53 & 0.12 & -0.17 & -0.36 & 1.00 & 0.88 \\
\hline $\mathrm{Al}$ & 0.61 & 0.17 & 0.01 & -0.63 & 0.88 & 1.00 \\
\hline
\end{tabular}

${ }^{\mathrm{a}}$ Correlations of horizontal variations were smaller and are not shown.

${ }^{\mathrm{b}}$ Hydraulic conductivity values were derived from the geophysical cross sections.

${ }^{\mathrm{c}}$ This is the sum of the Fe and Al. 


\section{A}
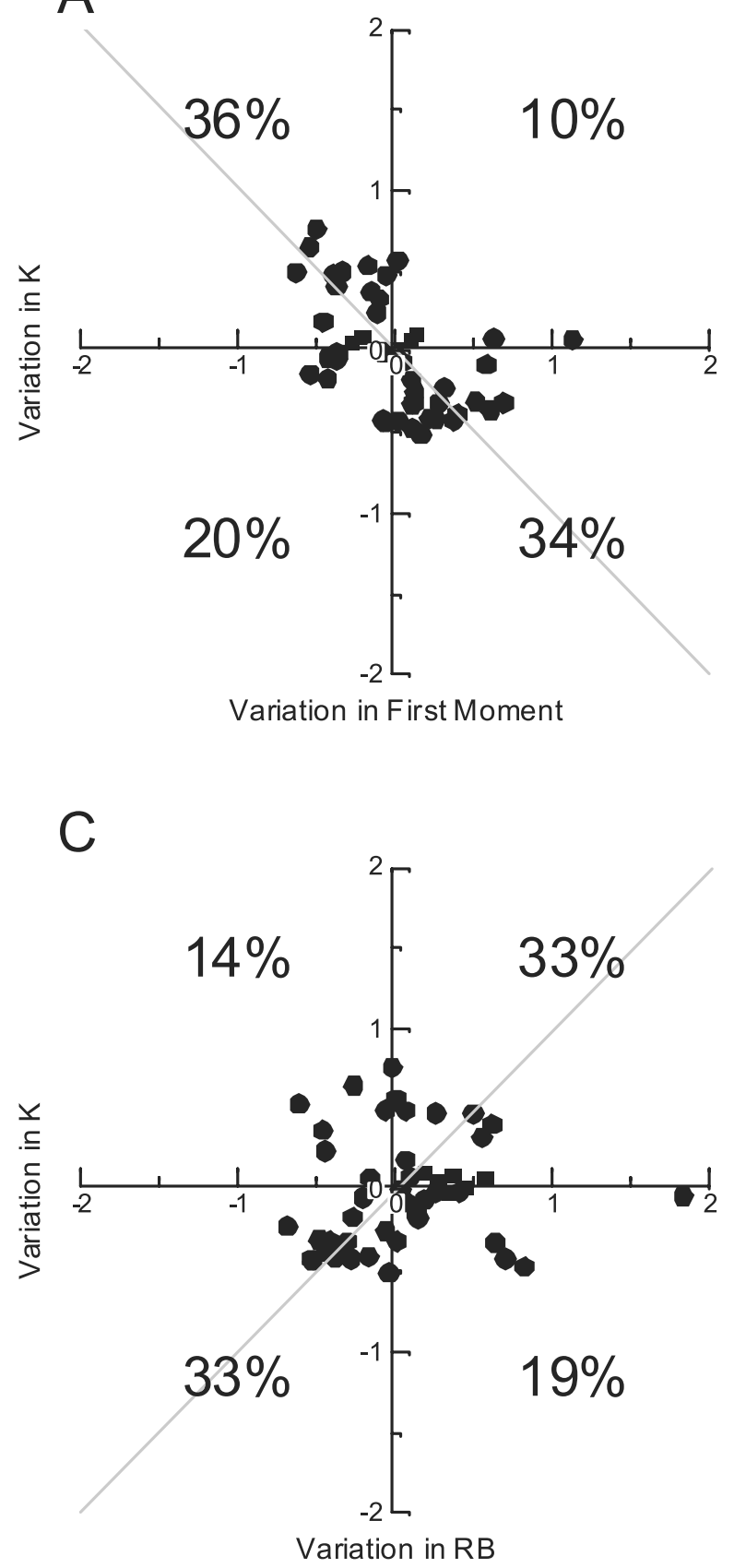
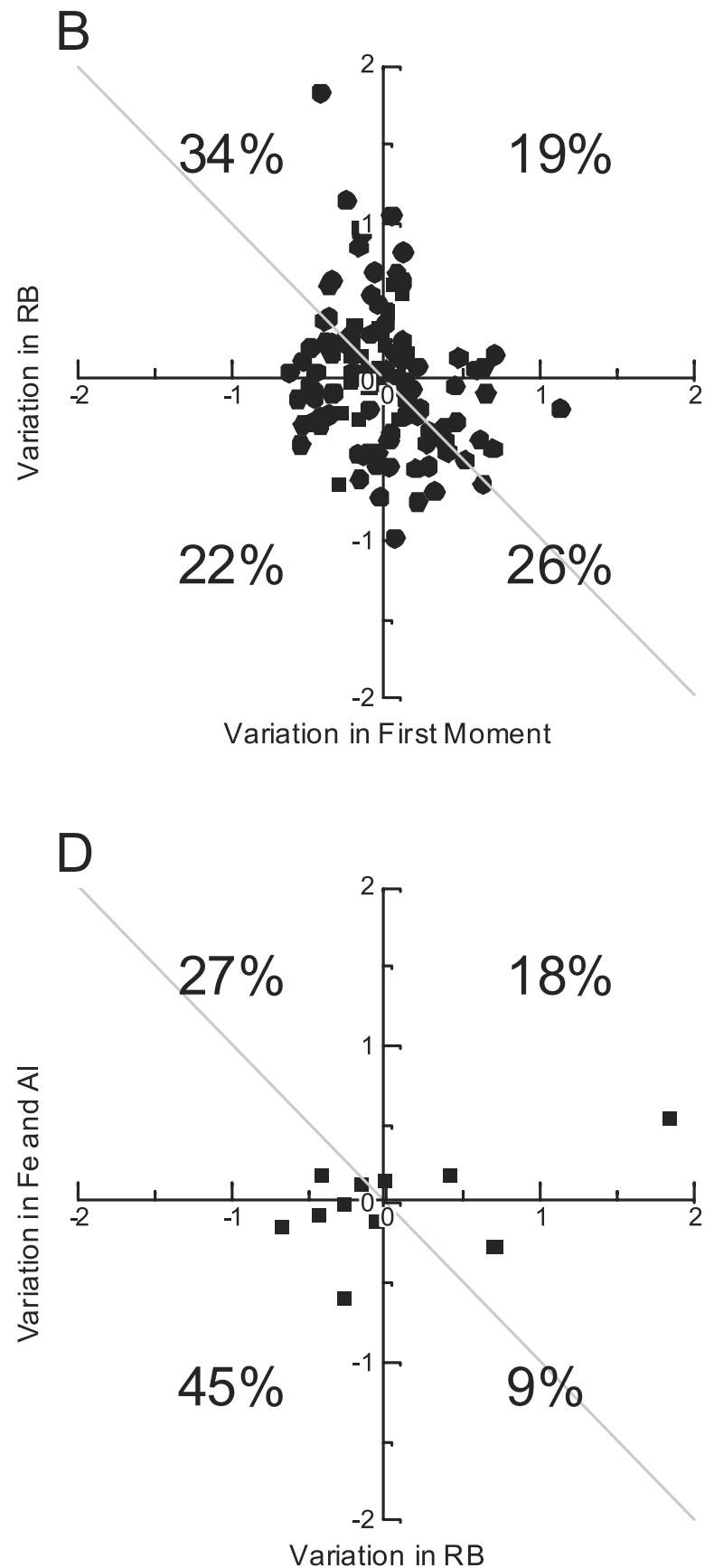

Figure 8. The correlation between (a) first moment of DA001 and hydraulic conductivity (K), (b) first moment of DA001 and RB of DA001, (c) RB of DA001, and K, and (d) RB of DA001 and extractable Fe and $\mathrm{Al}$ oxyhydroxides. Vertical comparisons are shown as circles, and horizontal variations are shown as squares. The shaded lines depict the direction of the predicted correlations. The numbers indicate the percentage of events falling in each quadrant. The correlations are reported in Table 2.

$\mathrm{RB}$ at shorter distances decreased faster than at samplers further down-gradient (Figures 5, 7, and 9). A weak correlation is sometimes, but not always, observed between hydraulic conductivity and RB with higher RB observed in $\mathrm{p} 8, \mathrm{p} 9$, and $\mathrm{p} 12$, in the higher conductivity layers relative to $\mathrm{p} 10$ and $\mathrm{p} 11$, the lower conductivity layer (e.g., S9, S10, and S11) (Table 2, Figure 8).

[33] Some variations in RB of DA001 were counterintuitive. The RB increased substantially from S14 to S17 and S21, with average values of $0.14,0.32$, and 0.29 , respectively (Figure 7). The RB was a factor of 2.3 greater at $\mathrm{S} 17$ and 2.1 greater at S21 compared with S14. In addition, the RB observed at $\mathrm{S} 10$ was both above and below values observed at S9 and S11 depending on the port. Since S9 and S11 are located off the main flow axis, it was originally expected that RBs at these samplers would be lower due to the greater travel distance. The RB at S16 and $\mathrm{S} 18$ was the same or higher than RB at S14 even with the longer travel distances and higher first moments (Figures 6 and 7). The RB was usually higher at the MLSs on the 

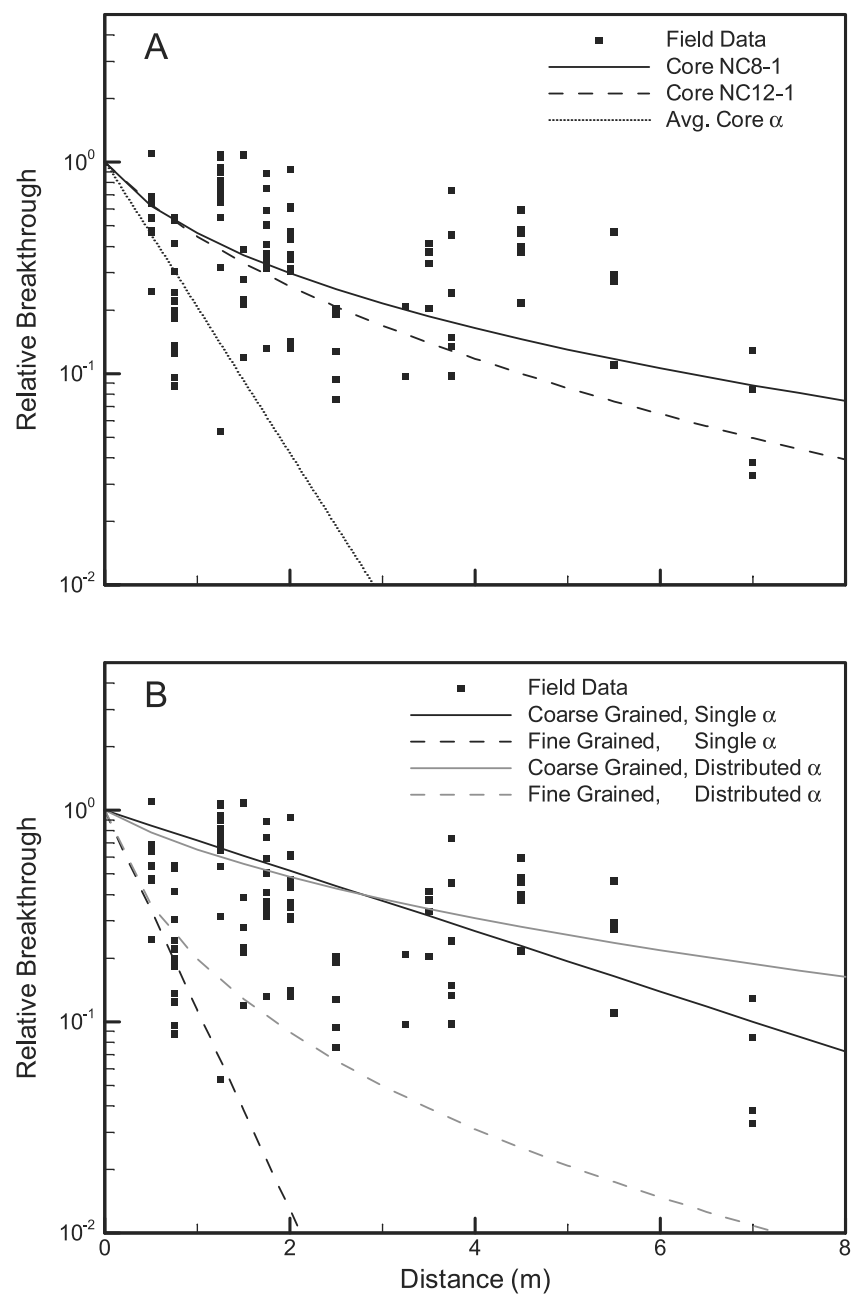

Figure 9. RB versus distance from the field experiment. (a) Predicted RB with distance utilizing a singular collision efficiency $(\alpha)$ value and the distribution calculated from the core data compared to RB values observed during the field injection. The calculations used an average groundwater velocity of $1 \mathrm{~m} / \mathrm{d}$ and a grain size of $354 \mu \mathrm{m}$. (b) The effect of heterogeneity on the predicted profile of RB with distance for a singular $\alpha$ value and for the same value of $\alpha$ but with a lognormal distribution. The $\log$ mean $\alpha$ was -2.32 , and the $\log \mathrm{SD}$ was 0.45 . The coarse-grained zone was $500 \mu \mathrm{m}$ with a groundwater velocity of $1.5 \mathrm{~m} / \mathrm{d}$, and the fine-grained zone was $250 \mu \mathrm{m}$ with a groundwater velocity of $0.5 \mathrm{~m} / \mathrm{d}$.

northeast side of the flow cell than to the corresponding MLS on the southwest side of the flow cell (Figure 7). For example, the RB at $\mathrm{S} 4$ was greater than $\mathrm{S} 7$ and $\mathrm{S} 9$ was greater than S11. Five sampling ports (S2 P10, S5 P7, P11, and P12, and S10 P9) close to the injection well exhibited RBs greater than 1 , averaging 1.08 , which was attributed to errors in the measurements used in the calculation.

[34] In order to calculate the exact $\alpha$ distribution for the field experiment the number of bacteria in the aqueous phase over the time course of the experiment would have to be known. The experimental design, samplers spaced farther apart than the size of the injected plume, enabled only rough estimates of the aqueous phase plume mass, and these data were not utilized in calculations. The number of sampling ports therefore was utilized to estimate the $\alpha$ distribution. Utilizing the sampling ports is a robust method, because the number of sampling ports decreases with distance and the MLS layout was designed to track bacterial attachment [Scheibe et al., 2001]. The $\alpha$ decreased with distance and at shorter distances had values similar to those obtained in core experiments (Figure 10a). The $\alpha$ distribution calculated from the field experiment spanned approximately 2 orders of magnitude from $2.4 \times 10^{-4}$ to $3.2 \times$ $10^{-2}$ (Figure 10). The field-based distribution appeared to be approximately lognormal distributed with a log mean and $\log \mathrm{SD}$ of $-2.56 \pm 0.43$. (Figure 10b). The jagged nature of the $\alpha$ distribution, however, may be caused by the choice of bins and the clumping of samplers at certain distances, for example, S5, S6, S9, S10, and S11 at approximately $1.5 \mathrm{~m}$ (Figure 1b).

\subsection{Error Analysis}

[35] Colloid filtration theory was developed for homogenous sand filters and requires singular values for grain size, porosity, and velocity at each port. These values vary over the complex three-dimensional flow paths that DA001 and $\mathrm{Br}$ travel. To account for these complexities, therefore, the observed variations and the errors in each parameter were propagated through the filtration equations to determine the error expected in the calculated $\alpha$ (Table 3). In this calculation the average RB and distance from the field data were utilized (Table 3). It was determined that each parameter individually would introduce errors from 6 to $29 \%$ in $\alpha$ and that cumulatively the maximum expected error would be $46 \%$ (Table 3). This is an upper estimate, because the covariance of the individual parameters was not included in this analysis, which would decrease calculated errors. This $46 \%$ error is small when compared with the observed 2 orders of magnitude variation in $\alpha$. The transport distance to each sampling port, which was only estimated because the three-dimensional flow equations were not solved, would impact the errors through the velocity and distance terms in the filtration equations. The velocity is the largest component of the error but is still small compared with the observed variations in $\alpha$, and thus the choice of distance is relatively arbitrary and does not significantly impact the results. Laboratory results indicate that the filtration theory may systematically under-predict the collector efficiency $(\eta)$ [Martin et al., 1996]. A systematic under-prediction of $\eta$ would cause an overestimation of $\alpha$ that increased with distance. Since we are examining a relatively narrow range of distances ( 0.5 to $7 \mathrm{~m}$ ) and $\alpha$ decreases with distance, this potential bias appears to have a minimal impact on the calculated $\alpha$ distribution. In conclusion, the variation in $\alpha$ due to errors in the calculations was most likely significantly smaller than the observed range.

\subsection{Scaling Intact Core Experiments}

[36] The $\alpha$ calculated from the core experiments all fell within the upper range of those from the field injection (Figure 10). A lognormal distribution was fit to the sorbed data from the intact core experiments. Utilizing this method produced $\alpha$ distributions from the intact core experiments similar to the one obtained for the field injection (Figure 10). The lognormal $\alpha$ distributions for cores NC8-1SAT and NC12-1SAT were best described by a log mean and log SD 

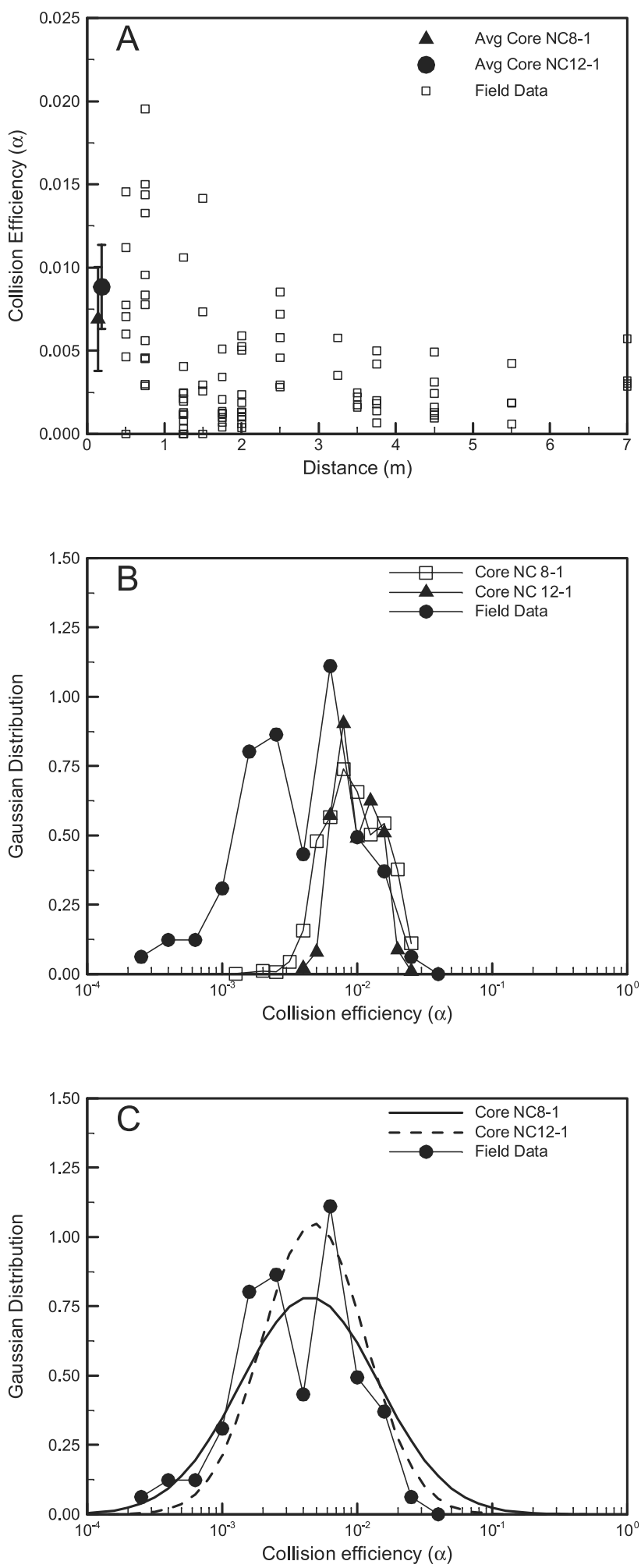

Figure 10. (a) Collision efficiency $(\alpha)$ versus distance for the field experiment at every sampling port and the average and standard deviation from two intact core experiments. Field data were calculated from breakthrough curves, and core data were calculated from sorbed profiles. (b) Calculated distribution of $\alpha$ from the field experiment and two intact core experiments. (c) Fitted Gaussian distribution of the core data. NC8-1SAT and NC12-1SAT had lognormal $\alpha$ distributions best described by a log mean and $\log \mathrm{SD}$ of $-2.35 \pm 0.51$ and $-2.32 \pm 0.38$, respectively. of $-2.35 \pm 0.51$ and $-2.32 \pm 0.38$, respectively (Figure 10c). The best fit values for the two- $\alpha$ model were $-2 \log \alpha$ for the high $\alpha,-3.1 \log \alpha$ for the low $\alpha$, and the fraction of high $\alpha$ was 0.94 (Figure 11). The two- $\alpha$ model could be used to predict the $\mathrm{RB}$ versus distance in the field data, but the calculated $\alpha$ distribution was different than both the field and core data (Figure 11). For this reason the lognormal distribution is utilized for the following sensitivity analysis. However, either distributive model has similar results when compared with uniform $\alpha$ value.

[37] Colloid filtration theory with a uniform $\alpha$ derived from core experiments significantly under-predicted RB, especially at distances greater than $2 \mathrm{~m}$ (Figure 9a). Utilizing an $\alpha$ distribution as compared with a uniform $\alpha$ greatly improved the predictions even with an average flow velocity and grain size from the field experiment $(1.0 \mathrm{~m} / \mathrm{d}$ and $354 \mu \mathrm{m}$, respectively) (Figure 9a).

[38] A sensitivity analysis was undertaken utilizing colloid filtration theory to determine whether an $\alpha$ distribution would increase or decrease the predicted vertical variation in RB. High- and low-permeability zones were represented with groundwater velocities of 1.5 and $0.5 \mathrm{~m} / \mathrm{d}$ and grain sizes of 500 and $250 \mu \mathrm{m}$, respectively. These values were not chosen to represent the largest variations observed at the site, but rather to bracket the variations observed at most of the MLSs. A uniform $\log$ mean of $\alpha(-2.32)$ and an $\alpha$ distribution $(-2.32 \pm 0.45)$ were used for this analysis. Results indicated that when utilizing a single $\alpha$, the predicted differences in RB between high- and low-permeability zones become larger than the observed range in $\mathrm{RB}$ at a distance of $2 \mathrm{~m}$ (Figure 9b). Utilizing an $\alpha$ distribution reduced the predicted range in $\mathrm{RB}$ between the high- and low-permeability zones (Figure 9b).

[39] Intrapopulation variations in bacterial properties could affect the SD of $\alpha$. Increasing the $\log$ SD of $\alpha$ for a given mean $\alpha$ increased the distance traveled but decreased the observed concentrations near the injection well (data not shown). A high $\log \mathrm{SD}$ of $\alpha$ produced a distribution of bacteria with high $\alpha$ that sorb near the well as well as bacteria with low $\alpha$ that travel a significant distance. When the injected bacteria have a range of surface properties, examining only the data obtained within the first meter may lead to gross underestimates of expected transport distances. On the basis of these analyses, it is apparent that if a low $\alpha$ subpopulation exists with a within a microbial community,

Table 3. Summary of Error Analysis for Calculation of $\alpha$

\begin{tabular}{lccc}
\hline \multicolumn{1}{c}{ Parameter } & Mean & $\begin{array}{c}\text { Standard } \\
\text { Deviation }\end{array}$ & $\begin{array}{c}\text { Expected } \\
\text { Percent Error }\end{array}$ \\
\hline Porosity (-) & 0.34 & $0.05^{\mathrm{a}}$ & 20 \\
Velocity, m/d & 0.72 & $0.34^{\mathrm{b}}$ & 29 \\
Bacterial diameter, $\mu \mathrm{m}$ & 1.00 & $0.10^{\mathrm{a}}$ & 6 \\
Grain size, $\mu \mathrm{m}$ & 354 & $46.3^{\mathrm{b}}$ & 15 \\
Bacterial density, $\mathrm{kg} / \mathrm{m}^{3}$ & 1060 & $106^{\mathrm{a}}$ & 20 \\
$\mathrm{RB}(-)$ & 0.41 & $.0328^{\mathrm{b}, \mathrm{c}}$ & 9 \\
Distance, m & 2.35 & $0.235^{\mathrm{a}}$ & 10 \\
Error from all parameters & & & 46 \\
\hline
\end{tabular}

${ }^{\text {a }}$ Standard deviation was estimated and was used as a way of assessing error

${ }^{\mathrm{b}}$ Standard deviation was directly calculated from the data.

${ }^{\mathrm{c}}$ This error is calculated from the standard deviation of the errors in calculating $\mathrm{RB}$, not the standard deviation of all RB values. 

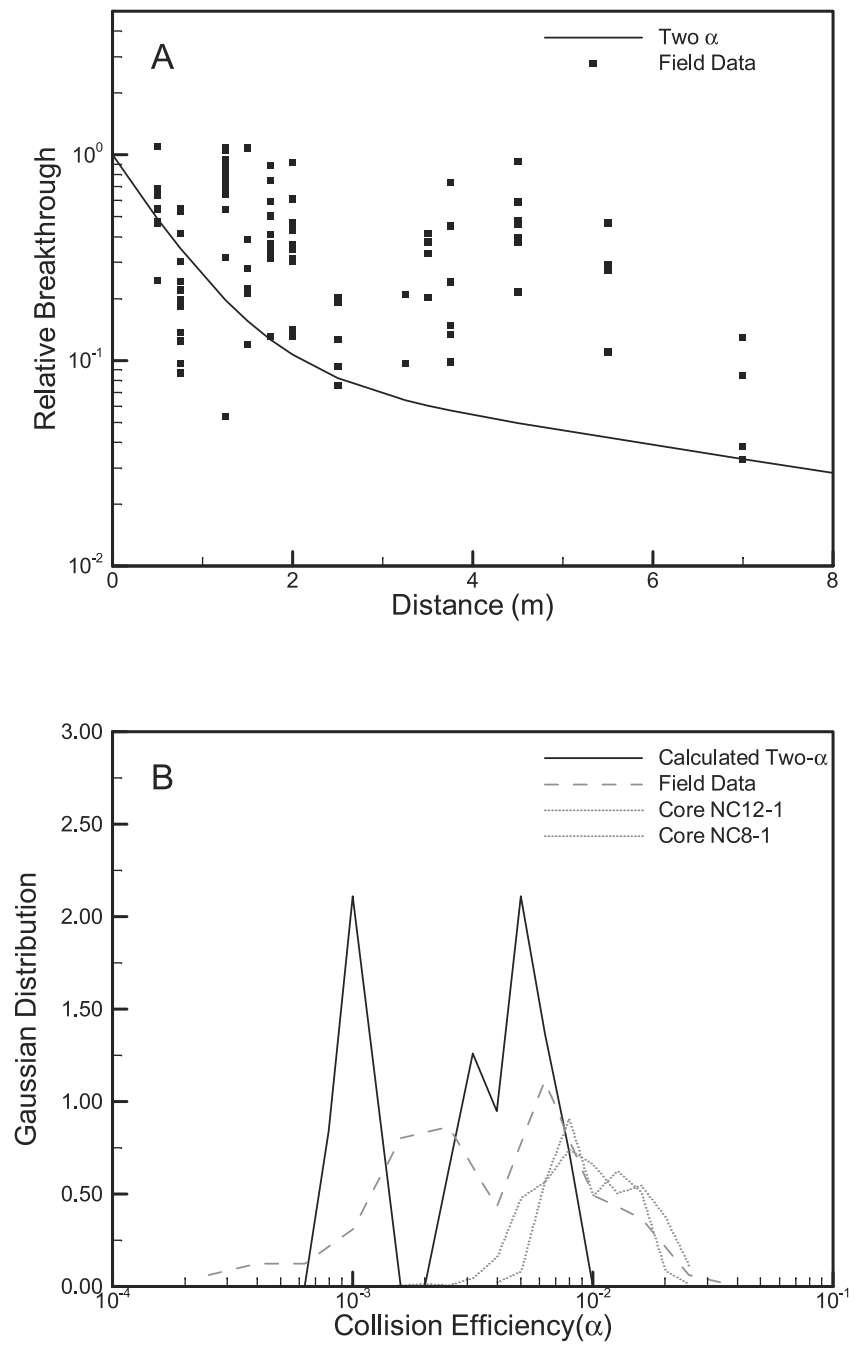

Figure 11. (a) Fit RB using a two- $\alpha$ model. (b) The calculated $\alpha$ distribution from the RB data if a two- $\alpha$ model is utilized. The $\alpha$ high is 0.01 , $\alpha$ low is 0.00096 , and fraction high is 0.94 , which represents values that best fit the intact core data $\alpha$ distribution and could reproduce the observed RB at the field scale.

independent of the shape of the distribution, significant transport could occur at the field scale.

\section{Discussion}

[40] Vertical and horizontal heterogeneity strongly impacted the first moment of the injected tracers (Figures 5, 6, and 8). For example, the breakthrough in S10 p9 was almost complete before a significant increase in concentration was seen at S10 p10 (Figure 5). These ports are only separated vertically by $27 \mathrm{~cm}$ and possess less than one half an order of magnitude difference in hydraulic conductivity (Figures 2 and 3). Even in what is considered a generally uniform sandy aquifer with maximum variations in hydraulic conductivity of approximately 1 order of magnitude, significant variations in the travel times of each tracer were still easily observed. These results indicate that flow was horizontal and little to no vertical mixing occurred. Comparison of variations in the first moment to the geophysical estimate of hydraulic conductivity showed a correlation, and the fastest arrival times or lowest first moments occurred in zones of higher hydraulic conductivity (Table 2, Figure 8a).

[41] Physical heterogeneity had an impact on the direction of movement for the injected plume. MLS 9 is located in an area that possesses high hydraulic conductivity (Figures 2 and 3). This zone of higher hydraulic conductivity may have acted as a preferential flow path channeling the plume around S10 to the northeast. If the bacteria observed at S14 represent those moving through the lowconductivity zone near S10, this explains the higher attachment rates and lower RB observed at S14. Using the same rationale, the higher RB at S5, S6, S9, S17, and S19 likely resulted from the plume following the preferential flow path around S10 and to the northeast. This movement of the tracer plume may also account for the double and elongated peak of Br seen at S14 p8 and p9 (Figure 5). The movement of the plume off the main flow axis was not caused by an eastward gradient in the water table because pumping rates were increased at $\mathrm{NC}-\mathrm{C} 3$ and decreased at NC-A3 to force the plume down the flow axis after the same effect was observed during preliminary $\mathrm{Br}$ injections. In addition, monitoring of water levels throughout the experiment showed no easterly gradient. These data indicate that any variation in the flow paths toward the east was caused by heterogeneity and that areas of high hydraulic conductivity controlled the direction of plume migration.

[42] Laboratory studies predict that even after small travel distances, large differences in attachment should be observed between coarse-grained and fine-grained zones [Fontes et al., 1991; Ren et al., 2000]. In $14 \mathrm{~cm}$ long columns, recovery of bacteria eluted through either coarsegrained $(1.00 \mathrm{~mm}$ diameter $)$ or fine-grained $(0.33 \mathrm{~mm}$ diameter) sediments varied by as much as 1 order of magnitude [Fontes et al., 1991]. Laboratory studies have also directly related attachment rates to variations in hydraulic conductivity [Ren et al., 2000]. Laboratory experiments using intact cores collected from near NCFA indicated that physical heterogeneity is the predominant factor in controlling attachment [Dong et al., 2002a]. Examining intact sediment cores at the millimeter scale has shown significant variations in sorbed profiles due to variations in grain size [Bolster et al., 1999; Dong et al., 2002a]. For four $0.5 \mathrm{~m}$ cores analyzed, however, the amounts of breakthrough of DA001 were markedly similar (measured values of $0.53,0.58,0.61,0.67)$ [Dong et al., 2002a]. Colloid filtration theory utilizing the variations in grain size and fluid velocity at NCFA, and a bacterial population with a uniform $\alpha$ indicated that variations in RB greater than 1 order of magnitude should be observed after $2 \mathrm{~m}$ of transport during this field injection (Figure 9).

[43] The RB data indicated that zones of low attachment rates occurred, but usually at most samplers little vertical variability existed (Figure 7). Comparison of the variability in first moments to RB revealed little correlation; whereas comparison of variability in RB to hydraulic conductivity showed a greater, yet still low correlation (Table 2, Figures $8 \mathrm{~b}$ and $8 \mathrm{c}$ ). This indicated that the layering at the site, which strongly affected first moments, had little to no affect on DA001 attachment rates. This is surprising given the effect of preferential flow paths and previous studies conducted at the laboratory scale. 
[44] Laboratory studies have indicated that other factors could have contributed to the observed variations in attachment rates including growth and predation [Kinner et al., 1997], variations in $d_{10}$ [Martin et al., 1996], the amount of iron oxides [Knapp et al., 1998], dissolved natural organic matter [Johnson and Logan, 1996], pH [Jewett et al., 1995; Scholl et al., 1990], ionic strength [Mills et al., 1994], and bivalent cations [Simoni et al., 2000]. Little or no growth of the injected cells occurred during the time frame of the experiment [Fuller et al., 2001]. Predation of the injected bacteria was minimal and would have slightly decreased the RB [Zhang et al., 2001]. Examination of the $d_{10}$ values from the site indicated that they vary by about 1 phi, a factor of 2 (data not shown), which is smaller than the observed variations in mean grain size, which varied by about 2 phi, a factor of 4 (Figure 2). No correlation was observed between $\mathrm{RB}$ and mean grain size or $d_{10}$ (correlations $<0.15$ ), indicating these may be secondary factors in controlling attachment. $\mathrm{A}$ correlation was observed between $\mathrm{Fe}$ and $\mathrm{Al}$ oxyhydroxides and RB (Table 2, Figure 8d); however, the correlation was in the direction opposite that predicted from laboratory experiments. The groundwater chemistry, including $\mathrm{pH}$, ionic strength, and bivalent cations, was relatively constant throughout the NCFA flow cell with slight increases near p10 and $\mathrm{p} 12$. The higher ionic strength, the smaller grain sizes, the higher Fe and $\mathrm{Al}$ content most likely associated with the finer grain sizes all located in the zone from p10 to p12 suggest that bacterial attachment would be greater there, but this was not observed. No single property of the site was a major factor in controlling bacterial attachment, and only a weak correlation between hydraulic conductivity and bacterial attachment was observed (Figure 8).

[45] Compared with chemical tracers, each bacterium in a single strain grown in the same culture can have slightly different properties, and these may change over time (e.g. size, density, charge, etc.). These differences in properties could potentially affect transport. These variations in bacterial properties may contribute to produce the lognormal $\alpha$ distribution. Numerical simulations utilizing the $\alpha$ distribution indicated that incorporating this distribution into colloid filtration theory could be utilized to better predict transport. The calculations indicate that a lognormal $\alpha$ distribution better represented the data than a two- $\alpha$ model, but it is not certain which, if either, distribution truly represented the bacterial population. It was not readily apparent what physiological characteristics might cause these observed $\alpha$ distributions. In column experiments conducted with bacterial strain B13, the variations in size, hydrophobicity, and charge were small after passage through a column, and these differences were not believed to be capable of producing the observed decrease in $\alpha$ with distance [Simoni et al., 1998]. Capillary electrophoresis of a monoclonal bacterial culture has exhibited two peaks, but the differences between the peaks were relatively small and predictive models indicated the difference should still produce a near-uniform $\alpha$ for each monoclonal culture [Albinger et al., 1994]. Within laboratory grown cultures each bacterium may have slightly different cell properties [Busscher et al., 2000; van der Mei and Busscher, 2001]. For example, not every bacterium in the same culture may possess similar fimbriae and fimbrils [Busscher et al., 2000]. Variations in other cell characteristics across strains, but not within a single strain, have been able to account for variations in transport [DeFlaun et al., 1999; Gannon et al., 1991]. For instance, some studies have suggested that variations in the lipopolysaccharide (LPS) of the bacteria may affect $\alpha$ [Williams and Fletcher, 1996]. Other studies have indicated that changes in the type, structure, and quantity of outer membrane proteins can also influence bacterial attachment [Caccavo, 1999]. Additionally, bacteria introduced into groundwater may become coated with inorganic and/or organic substances, which could potentially modify the cell surface properties [Johnson and Logan, 1996; Simoni et al., 2000]. These coatings would not be present during laboratory experiments utilizing artificial groundwater and clean sediments and therefore cannot be utilized to explain all of the observed variations in $\alpha$. Subtle distributions in one or more properties of each cell in a population may conspire to produce the observed variation in $\alpha$.

[46] Current methods of characterizing bacteria at an adequate resolution without altering the cell properties and the associated mechanistic models to estimate $\alpha$ from first principals are currently incapable of accurately predicting laboratory and field-scale bacterial transport [Baygents et al., 1998; Dong et al., 2002b; Pembrey et al., 1999]. Until the bacteria/mineral interaction processes can be adequately modeled, an applied approach, which includes intact core studies and analyses of the sorbed population, may provide a method for predicting field-scale bacterial transport. The method employed in this study could not account for all the small variations observed in RB but did capture the major trends occurring at the field scale. This $\alpha$ distribution could easily be integrated into a fully coupled three-dimensional flow and transport model and should provide further insight into the parameters controlling field-scale bacterial transport [Bolster et al., 1999; Scheibe et al., 2001]. Understanding and/or controlling the mean and standard deviation of a values may be imperative for successfully transporting, and predicting transport of microorganisms in the subsurface. This is critical for effective bioaugmentation of contaminated sites and protection of groundwater supplies.

[47] The variability in the microbial population was large enough that the effect of aquifer heterogeneity on attachment became inconsequential, especially for DA001, which has near-optimum transport properties. During this injection a chromatographic separation of DA001 occurred, with the stickiest bacteria attaching near the injection well and the bacteria with the near-optimum transport properties moving the farthest. The normalized difference across the variation in the bacterial strain was greater than the aquifer heterogeneity at the site, making it appear like aquifer heterogeneity did not affect transport. The microbial heterogeneity effectively masked the effect of aquifer heterogeneity on transport, which is observable at the smaller scale. At the millimeter scale a uniform subpopulation of DA001 was sampled and the effect of heterogeneity on grain size was easily observed [Dong et al., 2002a]. At larger scales, a heterogeneous DA001 population was sampled and the effect of aquifer heterogeneity on transport became masked.

[48] Acknowledgments. The investigators would like to acknowledge the support of the U.S. Department of Energy (DOE), Office of Energy Research (OER), and the DOE Natural and Accelerated Bioremediation Research Program (NABIR) Acceleration Element (grant DE-FG0297ER62472). The authors would also like to acknowledge the leadership of 
Frank Wobber, the program manager for the Acceleration Element of NABIR. Access to the field site was granted by the Nature Conservancy, Virginia Coast Reserve. We would like to thank S. Hubbard and J. Chen for help interpreting the site heterogeneity and A. Beavis for help with the flow cytometry. Reviews by W. Johnson and multiple anonymous reviewers greatly improved this manuscript. This work could not have been completed without the field support of T. Griffin, T. Scheibe, J. Seebald, J. O'Reilly, J. Sliko, K. Long, L. Elkins, W. Johnson, P. Zheng, F. Dobbs, K. Choi, S. Vainberg, W. Kovacik, E. Alvarez, and C. Hemingway.

\section{References}

Albinger, O., B. K. Biesemeyer, R. G. Arnold, and B. E. Logan, Effect of bacterial heterogeneity on adhesion to uniform collectors by monoclonal populations, FEMS Microbiol. Lett., 124, 321-326, 1994.

Bales, R. C., S. R. Hinkle, T. W. Kroeger, K. Stocking, and C. P. Gerba, Bacteriophage adsorption during transport through porous media: Chemical perturbations and reversibility, Environ. Sci. Technol., 25, 20882095, 1991.

Bales, R. C., S. Li, K. M. Maguire, M. T. Yahya, and C. P. Gerba, MS-2 and poliovirus transport in porous media: Hydrophobic effects and chemical perturbations, Water Resour. Res., 29(4), 957-963, 1993.

Bales, R. C., S. Li, K. M. Maguire, M. T. Yahya, C. P. Gerba, and R. W. Harvey, Virus and bacteria transport in a sandy aquifer, Cape Cod, MA Ground Water, 33(4), 653-661, 1995.

Bales, R. C., S. Li, T.-C. J. Yeh, M. E. Lenczewski, and C. P. Gerba, Bacteriophage and microsphere transport in saturated porous media: Forced-gradient experiment at Borden, Ontario, Water Resour. Res., 33(4), 639-648, 1997.

Baygents, J. C., J. R. Glynn Jr., O. Albinger, B. K. Biesemeyer, K. L. Ogden, and R. G. Arnold, Variation of surface charge density on monoclonal bacterial populations: Implications for transport through porous media, Environ. Sci. Technol., 32, 1596-1603, 1998.

Bevington, P. R., and D. K. Robinson, Data Reduction and Error Analysis for the Physical Sciences, 327 pp., McGraw-Hill, New York, 1992.

Bolster, C. H., A. L. Mills, G. M. Hornberger, and J. S. Herman, Spatial distribution of deposited bacteria following miscible displacement experiments in intact sediment cores, Water Resour. Res., 35(6), $1797-$ $1807,1999$.

Busscher, H. J., R. Bos, H. C. van der Mei, and P. S. Handley, Physiochemistry of microbial adhesion from an overall approach to the limits, in Physical Chemistry of Biological Interfaces, edited by A. Baszkin and W. Norde, pp. 431-458, Marcel Dekker, New York, 2000.

Caccavo, F. J., Protein-mediated adhesion of the dissimilatory Fe(III)reducing bacterium Shewanella alga $\mathrm{BrY}$ to hydrous ferric oxide, Appl. Environ. Microbiol., 65(11), 5017-5022, 1999.

Camesano, T. A., and B. E. Logan, Influence of fluid velocity and cell concentration on the transport of motile and nonmotile bacteria in porous media, Environ. Sci. Technol., 32, 1699-1708, 1998.

Campbell Rehmann, L. L., and C. Welty, Stochastic analysis of virus transport in aquifers, Water Resour. Res., 35(7), 1987-2006, 1999.

Chen, J., S. Hubbard, and Y. Rubin, Estimating the hydraulic conductivity at the South Oyster site from geophysical tomographic data using Bayesian techniques based on the normal linear regression model, Water Resour. Res., 37(6), 1603-1613, 2001.

Cole-Parmer, Operating Instructions for Bromide Electrodes, 15 pp., Vernon Hills, Ill., 2000.

DeFlaun, M. F., C. J. Murray, W. Holben, T. Scheibe, A. Mills, T. Ginn, T. Griffin, E. Majer, and J. L. Wilson, Preliminary observations on bacterial transport in a coastal plain aquifer, FEMS Microbiol. Rev. 20, 473-487, 1997

DeFlaun, M. F., S. R. Oppenheimer, S. Streger, C. W. Condee, and M. Fletcher, Alterations in adhesions, transport, and membrane characteristics in an adhesion-deficient pseudomonad, Appl. Environ. Microbiol., 65(2), 759-765, 1999.

DeFlaun, M., M. Fuller, P. Zhang, W. Johnson, B. Mailloux, W. Holben, W. Kovacik, D. Balkwill, and T. Onstott, Comparison of methods for monitoring bacterial transport in the subsurface, J. Microbiol. Methods, 47, 219-231, 2001

Dong, H. L., T. C. Onstott, M. F. Deflaun, M. E. Fuller, T. D. Scheibe, S. H. Streger, R. K. Rothmel, and B. J. Mailloux, Relative dominance of physical versus chemical effects on the transport of adhesion-deficient bacteria in intact cores from South Oyster, Virginia, Environ. Sci. Technol., 36(5), 891-900, 2002a.

Dong, H. L., T. C. Onstott, C. H. Ko, A. D. Hollingsworth, D. G. Brown, and B. J. Mailloux, Theoretical prediction of collision efficiency between adhesion-deficient bacteria and sediment grain surface, Colloids Surf. B, 24(3-4), 229-245, 2002b.

Duba, A. G., K. J. Jackson, M. C. Jovanovich, R. B. Knapp, and R. T. Taylor, TCE remediation using in situ resting-state bioaugmentation, Environ. Sci. Technol., 30(6), 1982-1989, 1996.

Ellis, D. E., E. J. Lutz, J. M. Odom, R. J. Buchanan, Jr., C. L. Bartlett, M. D. Lee, M. R. Harkness, and K. A. Deweerd, Bioaugmentation for accelerated in situ anaerobic bioremediation, Environ. Sci. Technol., 34, 22542260, 2000.

Fontes, D. E., A. L. Mills, G. M. Hornberger, and J. S. Herman, Physical and chemical factors influencing transport of microorganisms through porous medium, Appl. Environ. Microbiol., 57(9), 2473-2481, 1991.

Freeze, R. A., and J. A. Cherry, Groundwater, Prentice-Hall, Old Tappan, N. J., 1979

Fuller, M., H. Dong, B. Mailloux, T. Onstott, and M. DeFlaun, Examining bacterial transport in intact cores from Oyster, Virginia: Effect of facies type on bacterial breakthrough and retention, Water Resour. Res., 36(9), 2417-2431, 2000a.

Fuller, M., S. Streger, R. Rothmel, B. Mailloux, T. Onstott, J. Fredrickson, D. Balkwill, and M. DeFlaun, Development of a vital fluorescent staining method for monitoring bacterial transport in subsurface environments, Appl. Environ. Microbiol., 66(10), 4486-4496, 2000b.

Fuller, M. E., B. Mailloux, P. Zhang, J. A. Hall, S. Vainberg, W. Johnson, T. C. Onstott, and M. F. DeFlaun, Field-scale evaluation of CFDA/SEstaining coupled with multiple detection methods for assessing the transport of bacteria in situ, FEMS Microbiol. Ecol., 37(1), 55-66, 2001.

Gannon, J., V. B. Manilal, and M. Alexander, Relationship between cell surface properties and transport of bacteria through soil, Appl. Environ. Microbiol., 57(1), 190-193, 1991.

Garabedian, S. P., D. R. Leblanc, L. W. Gelhar, and M. A. Celia, Largescale natural gradient tracer test in sand and gravel, Cape Cod, Massachusetts: 2. Analysis of spatial moments for a nonreactive tracer, Water Resour. Res., 27(5), 911-924, 1991.

Glynn, J. R., Jr., B. M. Belongia, R. G. Arnold, K. L. Ogden, and J. C. Baygents, Capillary electrophoresis measurements of electrophoretic mobility for colloidal particles of biological interest, Appl. Environ. Microbiol., 64(7), 2572-2577, 1998

Green, M., D. J. Swift, J. Chen, S. Hubbard, E. L. Majer, and C. Murray, Heterogeneity at the Narrow Channel Site, Oyster, VA: A statistical approach to assess the sedimentary facies prior to correlation with permeability and geophysical imaging, Eos Trans. AGU, 81(19), Spring Meet. Suppl., Abstract H51A-08, 2000.

Harvey, R. W., Microorganisms as tracers in groundwater injection and recovery experiments: A review, FEMS Microbiol. Rev., 20, 461-472, 1997.

Harvey, R. W., and S. P. Garabedian, Use of colloid filtration theory in modeling movement of bacteria through a contaminated sandy aquifer, Environ. Sci. Technol., 25, 178-185, 1991.

Harvey, R. W., L. H. George, R. L. Smith, and S. R. LeBlanc, Transport of microspheres and indigenous bacteria through a sandy aquifer: Results of natural- and forced-gradient tracer experiments, Environ. Sci. Technol., 23, 51-56, 1989.

Harvey, R. W., N. E. Kinner, D. MacDonald, D. W. Metge, and A. Bunn, Role of physical heterogeneity in the interpretation of small-scale laboratory and field observation of bacteria, microbial-sized microsphere, and bromide transport through aquifer sediments, Water Resour. Res., 29(8), 2713-2721, 1993.

Harvey, R. W., N. E. Kinner, A. Bunn, D. MacDonald, and D. Metge, Transport behavior of groundwater protozoa and protozoan-sized microspheres in sandy aquifers, Appl. Environ. Microbiol., 61(1), 209-217, 1995.

Holben, W. E., and P. H. Ostrom, Monitoring bacterial transport by stable isotope enrichment of cells, Appl. Environ. Microbiol., 66, 4935-4939, 2000

Hubbard, S. S., J. Chen, J. Peterson, E. Majer, K. Williams, D. J. Swift, B. Mailloux, and Y. Rubin, Hydrogeological characterization of the South Oyster bacterial transport site using Geophysical Data, Water Resour. Res., 37(10), 2431-2456, 2001

Hyndman, D. W., et al., Hydraulic characterization and design of a fullscale biocurtain, Ground Water, 38(3), 462-474, 2000.

Jewett, D. G., T. A. Hilbert, B. E. Logan, R. G. Arnold, and R. C. Bales, Bacterial transport in laboratory columns and filters: Influence of ionic strength and $\mathrm{pH}$ on collision efficiency, Water Resour., 29(7), 1673$1680,1995$.

Johnson, W. P., and B. E. Logan, Enhanced transport of bacteria in porous media by sediment-phase and aqueous-phase natural organic matter, Water Resour, 30(4), 923-931, 1996. 
Johnson, W. P., M. J. Martin, M. J. Gross, and B. E. Logan, Facilitation of bacterial transport through porous media by changes in solution and surface properties, Colloids Surf. A, 107, 263-271, 1996.

Johnson, W. P., et al., Ferrographic tracking of bacterial transport in the field at the narrow channel focus area, Oyster, VA, Environ. Sci. Technol., 35(1), 182-191, 2001.

Kinner, N. E., R. W. Harvey, and M. Kazmierkiewicz-Tabake, Effect of flagellates on free-living bacterial abundance in an organically contaminated aquifer, FEMS Microbiol. Rev., 20, 249-259, 1997.

Knapp, E. P., J. S. Herman, G. M. Hornberger, and A. L. Mills, The effect of distribution of iron-hydroxide grain coatings on the transport of bacterial cells in porous media, Environ. Geol., 33(4), 243-248, 1998.

Logan, B. E., D. G. Jewett, R. G. Arnold, E. J. Bouwer, and C. R. O'Melia, Clarification of clean-bed filtration models, J. Environ. Eng., 121(12), $869-872,1995$

Mailloux, B. J., The effect of aquifer and microbial heterogeneity on the transport and activity of bacteria in the Columbia Aquifer, Oyster, Virginia, Ph.D. thesis, Princeton Univ., Princeton, N. J., 2003.

Martin, M. J., B. E. Logan, W. P. Johnson, D. G. Jewett, and R. G. Arnold, Scaling bacterial filtration rates in different sized porous media, J. Environ. Eng., 122(5), 407-415, 1996.

McCarthy, J. F., and J. M. Zachara, Subsurface transport of contaminants, Environ. Sci. Technol., 23, 496-503, 1989.

McKay, L. D., J. A. Cherry, R. C. Bales, M. T. Yahya, and C. P. Gerba, A field example of bacteriophage as tracers of fracture flow, Environ. Sci. Technol., 27, 1075-1079, 1993a.

McKay, L. D., R. W. Gillham, and J. A. Cherry, Field experiments in a fractured clay till: 2. Solute and colloid transport, Water Resour. Res., 29(12), 3879-3890, 1993b.

McKay, L. D., W. E. Sanford, and J. M. Strong, Field-scale migration of colloidal tracers in fractured shale saprolite, Ground Water, 38(1), 139147,2000

Mills, A. L., J. S. Herman, G. M. Hornberger, and T. H. DeJesus, Effect of solution ionic strength and iron coatings on mineral grains on the sorption of bacterial cells to quartz sand, Appl. Environ. Microbiol., 60(9), 3300-3306, 1994.

Morley, L. M., G. M. Hornberger, A. L. Mills, and J. S. Herman, Effects of transverse mixing on transport of bacteria through heterogeneous media, Water Resour. Res., 34(8), 1901-1908, 1998.

Murphy, E. M., T. R. Ginn, A. Chilakapati, C. T. Resch, J. L. Philips, T. W. Wietsma, and C. M. Spadoni, The influence of physical heterogeneity on microbial degradation and distribution in porous media, Water Resour. Res., 33(5), 1087-1103, 1997.

Pembrey, R. S., K. C. Marshall, and R. P. Schneider, Cell surface analysis techniques: What do cell preparation protocols do to cell surface properties, Appl. Environ. Microbiol., 65(7), 2877-2894, 1999.

Pieper, A. P., J. N. Ryan, R. W. Harvey, G. L. Amy, T. H. Illangasekare, and D. W. Metge, Transport and recovery of bacteriophage PRD1 in a sand and gravel aquifer: Effect of sewage-derived organic matter, Environ. Sci. Technol., 31, 1163-1170, 1997.

Rajagopalan, R., and C. Tien, Trajectory analysis of deep-bed filtration with the sphere-in-cell porous media model, AIChE J., 22(3), 523-533, 1976.

Ren, J., A. I. Packman, and C. Welty, Correlation of colloid collision efficiency with hydraulic conductivity of silica sands, Water Resour. Res., 36(9), 2493-2500, 2000.

Richardson, D. L., Hydrogeology and analysis of the ground-water-flow system of the Eastern Shore, Virginia, 108 pp., U.S. Geol. Surv., Denver, Colo., 1994

Ryan, J. N., and M. Elimelech, Colloid mobilization and transport in groundwater, Colloids Surf. A, 107, 1-56, 1996.
Ryan, J. N., M. Elimelech, R. A. Ard, R. W. Harvey, and P. R. Johnson, Bacteriophage PRD1 and silica colloid transport and recovery in an iron oxide-coated sand aquifer, Environ. Sci. Technol., 33, 63-73, 1999.

Scheibe, T. D., Y. Chien, and J. S. Radke, Use of quantitative models to design microbial transport experiments in a sandy aquifer, Ground Water, $39(2), 210-222,2001$

Scholl, M. A., and R. W. Harvey, Laboratory investigations on the role of sediment surface and groundwater chemistry in transport of bacteria through a contaminated sandy aquifer, Environ. Sci. Technol., 26(7), $1410-1417,1992$

Scholl, M. A., A. L. Mills, J. S. Herman, and G. M. Hornberger, The influence of mineralogy and solution chemistry on the attachment of bacteria to representative aquifer materials, J. Contam. Hydrol., 6 , $321-336,1990$

Simoni, S. F., H. Harms, T. N. P. Bosma, and A. J. B. Zehnder, Population heterogeneity affects transport of bacteria through sand columns at low flow rates, Environ. Sci. Technol., 32, 2100-2105, 1998.

Simoni, S. F., T. N. P. Bosma, H. Harms, and A. J. B. Zehnder, Bivalent cations increase both the subpopulation of adhering bacteria and their adhesion efficiency in sand columns, Environ. Sci. Technol., 34, 10111017, 2000.

Speiran, G. K., Geohydrology and geochemistry near coastal ground-waterdischarge areas of the Eastern Shore, Virginia, 72 pp., U.S. Geol. Surv., Denver, Colo., 1996.

Steffan, R. J., K. L. Sperry, M. T. Walsh, S. Vainberg, and C. W. Condee, Field-scale evaluation of in situ bioagumentation for remediaton of chlorinated solvents in groundwater, Environ. Sci. Technol., 33, $2271-$ 2781, 1999.

Turner, G. A., Heat and Concentration Waves, 233 pp., Academic, San Diego, Calif., 1972.

van der Mei, H. C., and H. J. Busscher, Electrophoretic mobility distributions of single-strain microbial populations, Appl. Environ. Microbiol. 67(2), 491-494, 2001

Williams, V., and M. Fletcher, Pseudomonas fluorescens adhesion and transport through porous media are affected by lipopolysaccharide composition, Appl. Environ. Microbiol., 62(1), 100-104, 1996.

Zhang, P., W. P. Johnson, T. D. Scheibe, K.-H. Choi, F. C. Dobbs, and B. J. Mailloux, Extended tailing of bacteria following breakthrough at the Narrow Channel focus area, Oyster, Virginia, Water Resour. Res., 37(11), 2687-2698, 2001.

Zhu, C., L. Penn, H. Xu, and D. Veblen, The influence of mineralogy on bacteria transport in Atlantic Coastal Plain aquifer, Eos Trans. AGU, 81(19), Spring Meet. Suppl., Abstract H41F-06, 2000.

M. F. DeFlaun, Geosyntec Consultants, Research Park, Princeton, NJ 08540, USA

H. Dong, Department of Geology, Miami University, Oxford, OH 45056, USA

M. E. Fuller, R. K. Rothmel, and S. H. Streger, Envirogen Inc., Princeton Research Center, 4100 Quakerbridge Road, Lawrenceville, NJ 08648, USA.

M. Green and D. J. P. Swift, Ocean, Earth, and Atmospheric Sciences, Old Dominion University, 4600 Elkhorn Avenue, Norfolk, VA 23529 USA.

J. Hall and T. C. Onstott, Department of Geosciences, Princeton University, Princeton, NJ 08544, USA.

B. J. Mailloux, Columbia Earth Institute, Columbia University, New York, NY 10115, USA. (bjm2103@columbia.edu)

J. Radke, Golder Associates, Atlanta, GA 30341, USA. 